\title{
Stoichiometry among bioactive trace metals in seawater on the Bering Sea shelf
}

\section{$\operatorname{AUTHOR}(\mathrm{S})$ :}

Cid, Abigail Parcasio; Urushihara, Syouhei; Minami, Tomoharu; Norisuye, Kazuhiro; Sohrin, Yoshiki

\section{CITATION:}

Cid, Abigail Parcasio ...[et al]. Stoichiometry among bioactive trace metals in seawater on the Bering Sea shelf. Journal of Oceanography 2011, 67(6): 747-764

\section{ISSUE DATE:}

2011-12

URL:

http://hdl.handle.net/2433/151713

\section{RIGHT:}

The final publication is available at www.springerlink.com; この論文は 出版社版でありません。引用の際には出版社版をご確認ご利用くださ $\omega_{\circ}$; This is not the published version. Please cite only the published version. 
1 Stoichiometry among Bioactive Trace Metals in Seawater on the Bering Sea Shelf

2

3 Abigail Parcasio Cid, Syouhei Urushihara, Tomoharu Minami, Kazuhiro Norisuye and
6 Institute for Chemical Research, Kyoto University, Uji, Kyoto 611-0011

7

$8 \quad *$ Corresponding author. E-mail: sohrin@scl.kyoto-u.ac.jp

9 Telephone: 81-774-38-3100; Fax: 81-774-38-3099

\section{Abstract}

12 The distribution of $\mathrm{Al}, \mathrm{Mn}, \mathrm{Fe}, \mathrm{Co}, \mathrm{Ni}, \mathrm{Cu}, \mathrm{Zn}, \mathrm{Cd}$, and $\mathrm{Pb}$ in seawater were investigated on 13 the Bering Sea shelf $\left(56-64^{\circ} \mathrm{N}, 165-169^{\circ} \mathrm{W}\right)$ in September 2000. The unfiltered and filtered seawater samples were used for determination of total dissolvable (TD) and dissolved (D) metals (M), respectively. The TD-M concentrations were generally higher than in the Pacific Ocean. TD-Cd was highest in deep water of the outer shelf domain and dominated by dissolved species. The other TD-M were highest at stations close to the Yukon River delta and had higher fractions of labile particulate (LP) species that were obtained as the difference between TD-M and D-M. Dissolved $\mathrm{Al}, \mathrm{Ni}$, and $\mathrm{Cu}$ were characterized by input from the Yukon River. Dissolved Mn and Co showed maximums on the bottom of the coastal domain, suggesting influence of sedimentary Mn reduction. The correlations of D-Zn, D-Cd, and macronutrients indicated their distributions were largely controlled through uptake by microorganisms and remineralization from settling particles. All these three processes (river input, sedimentary reduction, and biogeochemical cycle) had influence on the distribution of $\mathrm{D}-\mathrm{Fe}$. $\mathrm{D}-\mathrm{Pb}$ was fairly uniformly distributed in the study area. The 
1 stoichiometry of $\mathrm{D}-\mathrm{M}$ in the Bering Sea shelf showed enrichment of $\mathrm{Co}$ and $\mathrm{Pb}$ and depletion

2 of $\mathrm{Ni}, \mathrm{Cu}, \mathrm{Zn}$, and $\mathrm{Cd}$ compared to that in the North Pacific. The LP-M/LP-Al ratio revealed

3 significant enrichment of the other eight metals against the crustal abundance, suggesting

4 importance of formation of Fe-Mn oxides and adsorption of trace metals on the oxides.

6 Keywords: Eastern Bering Sea, seawater, bioactive trace metals, total dissolvable species, 7 dissolved species, labile particulate species, sectional distribution, enrichment factor, 8 stoichiometry, speciation.

$10 \quad 1 . \quad$ Introduction

11 The Bering Sea is a semi-enclosed high-latitude sea, exchanging water, materials, 12 and heat between the North Pacific and the Arctic Ocean through the Aleutian Archipelago 13 and the Bering Strait. The eastern Bering Sea is characterized by broad continental shelf that 14 is one of the most productive areas in the world ocean (Walsh et al., 1989). The 15 oceanography and biology in the Bering Sea seem particularly sensitive to climate change 16 because of seasonal ice cover (Grebmeier et al., 2006b; Sigler et al., 2010). The 17 southeastern Bering Sea shelf has undergone a warming of $\sim 3^{\circ} \mathrm{C}$ between 1995 and 2005 18 (Stabeno et al., 2007). Massive blooms of the coccolithophore Emiliania huxleyi caused the 19 first bright waters in summers of 1997-2000 (Merico et al., 2004).

Three hydrographic domains appear over the Bering Sea shelf in summer: the 21 coastal domain (0-50 m depth), the middle shelf domain (50-100 m depth), and the outer shelf 22 domain (100-170 m depth) (Coachman, 1986). The coastal domain is typically vertically 23 mixed and separated from the middle shelf domain by the inner front, which is located nearly 24 along the $50 \mathrm{~m}$ isobath with spatial variability depending on the wind and tidal strength (Kachel et al., 2002). The coastal domain receives direct effects of river discharge. The 
1 major river is the Yukon River, which is the longest river in Alaska delivering around $60 \times 10^{6}$

2 tons of suspended particles and more than $2 \times 10^{11} \mathrm{~m}^{3}$ of freshwater a year to the eastern

3 Bering Sea (Holmes et al., 2002). The middle shelf domain is stratified during summer,

4 forming the bottom water of low temperature and high nutrient. This bottom water is

5 referred to as the cold pool $\left(\leq 2^{\circ} \mathrm{C}\right)$ or the cool pool $\left(>2^{\circ} \mathrm{C}\right)$ (Stabeno et al., 2001). After

6 nitrate is depleted in the upper mixed layer during spring bloom, large quantities of

7 ammonium are produced in the bottom layer owing to denitrification in sediments (Koike and

8 Hattori, 1979; Tanaka et al., 2004). The outer shelf domain is separated from the middle

9 shelf domain by the middle front, centered near the $100 \mathrm{~m}$ isobath, and from the oceanic

10 domain by the shelf break front, centered near the $170 \mathrm{~m}$ isobath. The presence of shelf

11 fronts prevents cross-shelf exchange in the Bering Sea. The outer shelf domain develops a

12 warm wind-mixed surface layer, an intermediate layer, and a tidally mixed bottom layer

13 during summer. The annual primary production is lower in the surface waters of the oceanic

14 domain and higher from the shelf break to the coast (Rho and Whitledge, 2007). The band of high and sustained productivity observed approximately along the shelf break front is known as the Green Belt (Okkonen et al., 2004; Springer et al., 1996).

There are three key water masses that flow northward over the Bering Sea shelf into the Bering Strait in the open water season (Grebmeier et al., 2006a). More saline (> 32.5), nutrient-rich Anadyr Water (AW) flows on the western side of the northern Bering Sea, fresher $(<31.8)$, more nutrient-limited Alaska Coastal Water (ACW) flows on the eastern side of the Bering Sea, and a third water mass of intermediate salinity (31.8-32.5), Bering Shelf Water (BSW), lies between AW and ACW (Fig. 1). The major source of these water masses is the Aleutian North Slope Current (ANSC) that flows northeastward. Pacific water mainly comes from the passes along the Aleutian Archipelago, flows along ANSC and then along the Bering Slope Current (BSC) that flows in the upper $300 \mathrm{~m}$ over the slope to northwest, feeds 
1 into AW, and finally enters the Arctic Ocean.

Bioactive trace metals are essential to organisms and/or highly toxic at a high concentration. According to this extensive definition, we include $\mathrm{Al}, \mathrm{Mn}, \mathrm{Fe}, \mathrm{Co}, \mathrm{Ni}, \mathrm{Cu}, \mathrm{Zn}$, $\mathrm{Cd}$, and $\mathrm{Pb}$ in bioactive trace metals. Recently, knowledge about the distribution of these elements in the eastern Bering Sea has been increasing. Total dissolvable (TD) $\mathrm{Mn}$ and $\mathrm{Cu}$ have been measured in seawaters collected from the Bering Sea shelf (Heggie et al., 1987). It was proposed that continental shelf sediments are a source of $\mathrm{Mn}$ and $\mathrm{Cu}$ to the deep sea. During August 2003, the physicochemical speciation of dissolved (D) Fe was examined in surface and subsurface samples (Buck and Bruland, 2007), surface transects and vertical profiles of dissolved Fe and Mn were investigated (Aguilar-Islas et al., 2007), a vertical mixing event was simulated in shipboard incubation experiments in the middle shelf domain to investigate $\mathrm{Fe}$ and $\mathrm{Zn}$ cycling between the soluble, colloidal, and particulate size-fractions (Hurst and Bruland, 2007), and surface transects and vertical profiles of total and leachable particulate Fe, Mn, and Al, along with dissolved and soluble Fe were obtained (Hurst et al., 2010). These studies gave the following conclusions: (1) because D-Fe concentrations in surface outer shelf waters were depleted, the source of Fe to Green Belt waters was from the bottom layer of the outer shelf domain via enhanced vertical mixing at the shelf break. These outer shelf subsurface waters also provide macronutrients to the Green Belt; (2) the unusually high percentage of leachable particulate Fe was a potential major source of $\mathrm{Fe}$ for the phytoplankton community; (3) Fe reduction is taking place at an sediment/bottom water interface with denitrification, leading to subsequent oxidation and elevated concentrations of Fe in the bottom water; (4) D-Mn behaved relatively conservatively with respect to salinity and it can be used to trace the hydrographic domains of the Bering Sea.

In the present work, dissolved (D), total dissolvable (TD), and labile particulate (LP) concentrations of $\mathrm{Al}, \mathrm{Mn}, \mathrm{Fe}, \mathrm{Co}, \mathrm{Ni}, \mathrm{Cu}, \mathrm{Zn}, \mathrm{Cd}$, and $\mathrm{Pb}$ in seawater have been 
1 determined in order to achieve a better understanding of the distribution and behavior of these

2 metals in the eastern Bering Sea in summer. The results provide a comprehensive view on

3 biogeochemistry of the nine elements on the Bering Sea shelf.

4

5

6

\section{Sample Collections and Methods}

\subsection{Sampling locations}

Seawater samples were obtained during the cruise of R/V Mirai MR00-K06 in September 25, 2000 from eight stations on the eastern Bering Sea shelf (Fig. 1). Seawater samples were collected with Niskin-X bottles mounted on a CTD-rosette water sampling system (General Oceanics), of which frame was finished with epoxy paint. The inside of Niskin-X bottles was Teflon coated and thoroughly cleaned with detergent and $\mathrm{HCl}$ before the cruise. In order to decrease the possibility of contamination from the ship, the sampling was usually conducted as soon as possible after arrival at a station using a gallows crane. Operators of the sampling bottles wore plastic gloves.

The stations were labeled as BR plus number. The deepest station BR003 $\left(56.0^{\circ} \mathrm{N}\right.$, $166.0^{\circ} \mathrm{W} ; 109 \mathrm{~m}$ depth) was located northeast of the Bering Canyon (Fig. 1). BR005 $\left(57.0^{\circ} \mathrm{N}, 166.0^{\circ} \mathrm{W} ; 68 \mathrm{~m}\right)$ and BR007 $\left(58.0^{\circ} \mathrm{N}, 166.0^{\circ} \mathrm{W} ; 52 \mathrm{~m}\right)$ were located $\sim 240 \mathrm{~km}$ east of the Pribilof Islands. BR011 $\left(62.8^{\circ} \mathrm{N}, 166.8^{\circ} \mathrm{W} ; 27 \mathrm{~m}\right)$ and BR012 $\left(63.5^{\circ} \mathrm{N}, 165.5^{\circ} \mathrm{W} ; 29 \mathrm{~m}\right)$ were $\sim 100 \mathrm{~km}$ off the Yukon River delta. $\quad$ BR013 $\left(64.0^{\circ} \mathrm{N}, 167.0^{\circ} \mathrm{W} ; 29 \mathrm{~m}\right)$ was located in a pass from the Norton Sound to the Bering Strait.

\subsection{Water sampling and analytical methods}

Upon retrieval of the CTD-rosette water sampling system, the seawater samples were transferred to $500 \mathrm{ml}$ pre-cleaned low-density polyethylene bottles (LDPE, Nalge Nunc) at No. 1 CTD \& Water Drawing Room (not a clean room) of the vessel using a silicon tube 
1 and bell to avoid contamination of airborne particles. The samples were immediately

2 brought into Clean Room of the vessel. An aliquot of seawater $(250 \mathrm{ml})$ was filtered

3 through a $0.2 \mu \mathrm{m}$ precleaned Nuclepore filter (Coaster) by $\mathrm{N}_{2}$ gas pressure using a closed

4 filtration system. The interior of the filter holder was rinsed with pure water and the filter

5 was exchanged for each sample. The whole line of the filtration system was rinsed with

6 pure water after all samples were filtered for each station. The filtered seawater was added

7 with $\mathrm{HCl}$ (TAMAPURE AA-10, Tama Chemicals) to a final concentration of $0.01 \mathrm{M}$ and $\mathrm{pH}$

8 2.2. This subsample was used for the determination of dissolved trace metals (D-M). The

9 other aliquot of seawater $(250 \mathrm{ml})$ without filtration was added with a mixed acid to a final

10 concentration of $0.01 \mathrm{M} \mathrm{HCl}$ and $0.002 \mathrm{M} \mathrm{HF}$ (TAMAPURE AA-10), and used for the 11 determination of total dissolvable trace metals (TD-M). The low concentration of HF was 12 added to prevent adsorption to the walls of the bottles and precipitation of $\mathrm{Al}$ and $\mathrm{Fe}$ in high 13 concentration samples.

The seawater samples were stored at room temperature in our laboratory until analysis. Preconcentration of the bioactive trace metals was performed 6 and 9 years after collection, using the chelating resin on which ethylenediaminetriacetic and iminodiacetic acids are immobilized (NOBIAS CHELATE-PA1, Hitachi High-Technologies). The details of the analytical method have been reported elsewhere (Sohrin et al., 2008). The trace metals were collected from $120 \mathrm{ml}$ of seawater that had been adjusted to $\mathrm{pH} 6$ just before the preconcentration and eluted with $15 \mathrm{ml}$ of $1 \mathrm{M} \mathrm{HNO}_{3}$ (TAMAPURE AA-10).

Concentrations of D-M and TD-M in the eluent were mostly determined using an inductively coupled plasma mass spectrometer (Elan DRC II, Perkin Elmer) by a calibration curve method. The isotopes used for the determination were ${ }^{27} \mathrm{Al},{ }^{55} \mathrm{Mn},{ }^{54} \mathrm{Fe},{ }^{59} \mathrm{Co},{ }^{60} \mathrm{Ni}$, ${ }^{65} \mathrm{Cu},{ }^{68} \mathrm{Zn}$, ${ }^{114} \mathrm{Cd}$, and ${ }^{208} \mathrm{~Pb}$. Another isotopes were also measured for cross checking except mono-isotopic $\mathrm{Al}, \mathrm{Mn}$, and Co. High concentrations of total dissolvable $\mathrm{Al}, \mathrm{Mn}$, and $\mathrm{Fe}$ 
1 were determined using an inductively coupled plasma atomic emission spectrometer (Optima

22000 DV, Perkin Elmer) by a calibration curve method. The emission lines used were $3 \quad 396.153 ; 308.215 \mathrm{~nm}$ for $\mathrm{Al}, 257.410 ; 259.372 \mathrm{~nm}$ for $\mathrm{Mn}$, and $238.204 ; 239.562 \mathrm{~nm}$ for Fe.

4 The procedure blanks, detection limits, and results on analysis of seawater reference material $5 \quad$ NASS-5 (National Research Council of Canada) are listed in Table 1.

Temperature (T) was measured with the CTD. Salinity (S) was determined by conductivity on board the vessel. Dissolved oxygen was determined by the Winkler method.

The average standard deviation was $0.97 \mu \mathrm{mol} / \mathrm{kg}$ for replicate analysis. Macronutrients were measured on board with an AutoAnalyzer (TRAACSS). The average relative standard deviations were $0.12-0.90 \%$ for replicate analysis. Chlorophyll $a$ (Chl. $a$ ) was determined by fluorometry.

\section{Results}

\subsection{Hydrography}

Figure 2 shows sectional plots of oceanographic parameters in the study area. At the southern three stations, there were a surface mixed layer (0-30 m depth) and a deep layer. The cool pool $\left(\sim 2.6^{\circ} \mathrm{C}\right)$ appeared at BR005 $\left(57.0^{\circ} \mathrm{N}\right)$ and BR007 $\left(58.0^{\circ} \mathrm{N}\right)$. The northern five stations were mostly vertically mixed throughout the water column, except the cold bottom water $\left(\sim 1.2^{\circ} \mathrm{C}\right)$ at $\mathrm{BR} 010\left(62.0^{\circ} \mathrm{N}\right)$. Thus, BR003 $\left(56.0^{\circ} \mathrm{N}\right)$ was at the boundary between the outer shelf domain and the middle shelf domain. BR005 was in the middle shelf domain. BR007 was at the boundary between the middle shelf domain and the coastal shelf domain. All other stations were within the coastal domain. Waters in the surface layer of BR007 and at the stations in the coastal domain are classified as ACW, because S was less than 31.8. Waters in the surface layer of BR003 and 005 had S of 31.9-32.2, belonging to BSW. The decrease in $\mathrm{S}$ and increase in $\mathrm{T}$ result in substantial depletion in density 
1 between BR011 $\left(62.8^{\circ} \mathrm{N}\right)$ and BR012 $\left(63.5^{\circ} \mathrm{N}\right)$, indicating the intrusion of the Yukon River 2 freshwater.

Bright waters with a transparency less than $1 \mathrm{~m}$ were observed south of $62^{\circ} \mathrm{N}$ owing to massive blooming of Emiliania huxleyi (Merico et al., 2004). The bottom water at BR003 was rich in macronutrients including $24 \mu \mathrm{mol} / \mathrm{kg}$ nitrate, which should have originated from deep water ascending the Bering Canyon from the oceanic basin. A maximum of ammonium $(6 \mu \mathrm{mol} / \mathrm{kg})$ occurred in the cool pool of the middle shelf domain, being ascribed to sedimentary denitrification (Tanaka et al., 2004). Nitrate and silicate were mostly depleted in the coastal domain. In contrast, phosphate showed a bottom maximum around BR0010-012 concurrently with nitrite and ammonium, resulting in enrichment of phosphate against nitrate and silicate. Minor enrichment of phosphate was also detected in the cool pool of the middle shelf domain. It is likely that the excess phosphate has been accumulated as Fe-bound P (Zhang et al., 2010) and released from the reductive sediments.

Coastal stations had almost uniform oxygen concentrations at all depths, while oxygen decreased in depth at stations in the middle shelf domain. At the outer shelf station, the oxygen concentration decreased as macronutrients increased.

\subsection{Effect of storage time on the trace metal concentrations}

The Bering seawater samples were stored at normal room conditions and analysed in 2006 and re-analysed in 2009, 6 and 9 years after acidification, respectively. The change in concentrations was less than $20 \%$ for most TD-M and D-M. Significant increases were observed for TD-Al (2.7-fold in average), D-Al (3.1-fold), TD-Mn (1.3-fold), D-Mn (1.4-fold), TD-Ni (1.3-fold), and D-Pb (1.5-fold). All data of TD-Al and D-Al analysed in 2006 and 2009 were plotted in Fig. 3. The largest increases in TD-Al were observed at the coastal stations between $62.0-63.5^{\circ} \mathrm{N}$. Although the increases in D-Al were about one 
1 hundredth of those in TD-Al and more uniform over the shelf, significantly high increases in

2 D-Al were observed at BR007, BR011, and BR012. It has been reported the polypropylene 3 caps of LDPE bottles can be a source of Al contamination (Brown and Bruland, 2008). We

4 had cleaned the caps with hot $5 \mathrm{M} \mathrm{HF}$ to minimize the contamination. It is probable that the

5 increases were mainly caused by dissolution of $\mathrm{Al}$ from colloidal and suspended particles.

6 The large increases in TD-Al and D-Al occurred at stations where supply of terrigenous clay 7 minerals is expected from the Yukon River. It is likely that there were considerable 8 concentrations of colloidal $\mathrm{Al}$ in seawater. More rigorous pretreatment may be necessary to

9 determine the total concentrations of colloidal Al. These results clearly show that the 10 determined concentrations of trace metals are based on an operational definition. We expect, 11 however, TD-M that consists of D-M and LP-M can be a good measure of total bioavailable 12 metal. In this regard, concentrations of TD-M, D-M, and LP-M discussed in this paper are 13 focused on the analysis done after 9 years storage. The data of trace metals are summarized 14 in Appendix Table 1. Obviously contaminated data were removed from discussion.

3.3. Vertical profiles of bioactive trace metals at BR003, a station at the boundary between the outer and middle shelf domains

The vertical profiles of TD-M and D-M at BR003 are shown in Fig. 4. The typical concentration range s of D-M in the Pacific Ocean (Nozaki, 2001) are shown at the bottom of each panel for comparison. A striking feature is that the bioactive trace metals in seawater had considerably high concentrations at BR003. Particularly, the dissolved concentrations of $\mathrm{Mn}, \mathrm{Fe}$, and Co reached to 10-2000 times of the Pacific concentrations.

The dissolved concentrations of nutrient type elements, $\mathrm{Ni}, \mathrm{Cu}, \mathrm{Zn}$, and $\mathrm{Cd}$, were comparable to those in deep water of the Pacific Ocean. Another striking feature is high percentages of LP-species, of which concentrations are obtained as the difference between total dissolvable 
1 and dissolved concentrations. $\mathrm{Al}$ and Fe were totally dominated by LP-species in deep water

2 at $\mathrm{BR} 003 . \mathrm{Ni}, \mathrm{Cu}, \mathrm{Zn}$, and $\mathrm{Cd}$ also showed significant concentrations of LP-species

3 throughout the water column at BR003, whereas they are negligible in the North Pacific

4 Ocean (Ezoe et al., 2004).

6 3.4. Sectional distributions of dissolved metals on the Bering Sea shelf

The sectional distributions of D-M are shown in Fig. 5. The correlation matrix for

8 D-M, T, S, and Chl. $a$ is given in Table 2. D-M can be divided into four groups based on the

9 distribution and correlation: (1) $\mathrm{Al}, \mathrm{Fe}, \mathrm{Ni}$, and $\mathrm{Cu}$; (2) $\mathrm{Mn}$ and $\mathrm{Co}$; (3) $\mathrm{Zn}$ and $\mathrm{Cd}$; (4) $\mathrm{Pb}$.

D-Al, D-Fe, D-Ni, and D-Cu showed maximum concentrations at BR012 $\left(63.5^{\circ} \mathrm{N}\right)$.

11 The correlation coefficients of $\mathrm{D}-\mathrm{Fe}, \mathrm{D}-\mathrm{Ni}$, and $\mathrm{D}-\mathrm{Cu}$ with $\mathrm{D}-\mathrm{Al}$ were $0.60-0.69$. These

12 results indicate that the Yukon River is a significant source for these species in the coastal 13 domain.

14 D-Mn had maximum concentrations $(\sim 23 \mathrm{nmol} / \mathrm{kg})$ in the bottom water of BR009 $\left(60.0^{\circ} \mathrm{N}\right)$. This indicates Mn reduction in the sediments (Heggie et al., 1987). It should be noted that the bottom maximum of Mn was not coincident with that of ammonium. It is likely that denitrification is favorable in the cool pool in the middle shelf domain, because nitrate is available. Mn reduction may be favorable in the coastal domain, because there is significant supply of Mn from the Yukon River but nitrate is limited. D-Co showed a moderate correlation with D-Mn $(r=0.64)$. This is because Co(II) is oxidized on the surface of Mn oxides, scavenged from the water column, and released from the sediments by reduction of Mn oxides (Moffett and Ho, 1996; Tebo et al., 1984). Although surface depletion of D-Co indicative of biological utilization has been observed in the open ocean (Saito and Moffett, 2002), it was not detected in this study area. D-Fe was also relatively high in the bottom water with Mn maximums in the coastal domain. It is possible that redox 
1 potential decreased to produce Fe(II) in some portions of the sediments.

D-Cd exhibited strong correlations with macronutrients $(r=0.79-0.86)$. D-Zn

3 exhibited moderate correlations with macronutrients and D-Cd $(r=0.54-0.64)$. D-Cd and

$4 \mathrm{Zn}$ showed minimums in surface waters of the middle shelf domain, where the highest

5 concentrations of Chl. $a$ were observed. These results suggest that biogeochemical cycling,

6 including uptake by phytoplankton, downward transport by settling particles, and

7 remineralization in depth, is a major factor controlling the distribution of D-Cd and D-Zn.

8 D-Fe showed a slight increase in depth at BR003 $\left(56.0^{\circ} \mathrm{N}\right)$, while D-Ni and D-Cu did not

9 show a significant increase. For these elements, factors other than biogeochemical cycling

10 have prevailing effects on the distributions on the Bering Sea shelf.

$11 \quad \mathrm{D}-\mathrm{Pb}$ was distributed fairly uniformly and did not show a significant correlation 12 with any parameters. This may be ascribed to aeolian supply of $\mathrm{Pb}$. Relatively high 13 concentrations of D-Pb occurred at BR012 and BR013 $\left(64.0^{\circ} \mathrm{N}\right)$.

3.5. Sectional distributions of total dissolvable and labile particulate metals on the Bering Sea shelf

The sectional distributions of TD-M are shown in Fig. 6. The correlation matrix for TD-M, T, and S is given in Table 3. It is obvious that TD-M except TD-Cd had similar distributions and strongly correlated with each other $(r \geq 0.94)$. In general, TD-M concentrations increased northward with a maximum at BR012 $\left(63.5^{\circ} \mathrm{N}\right)$. There were negative and moderate correlations between TD-M and S $(r=-0.54--0.77)$. These results indicate the effect of riverine input of TD-M on inner shelf waters. In contrast, TD-Cd had the highest concentrations at the bottom of outer and middle shelf domains. Surface minimums of TD-Cd were detected at BR005 $\left(57.0^{\circ} \mathrm{N}\right)$, BR010 $\left(62.0^{\circ} \mathrm{N}\right)$, and BR013 $\left(64.0^{\circ} \mathrm{N}\right) . \quad \mathrm{TD}-\mathrm{Zn}$ also showed the minimum concentrations in surface water at BR005. 
The concentrations of LP-M were obtained as the difference between TD-M and

2 D-M concentrations. LP-M was assumed to be zero, when the concentration of D-M was

3 higher than that of TD-M. The sectional distributions of LP-M are shown in Fig. 7. The

4 correlation matrix for LP-M, T, S, and Chl. $a$ is given in Table 4. Similarly with TD-M,

$5 \quad$ LP-M except LP-Cd showed strong correlations with LP-Al $(r=0.95-0.98)$. LP-Cd was

6 moderately correlated with Chl. $a(r=0.68)$, suggesting importance of biogeochemical 7 cycling for this element.

9 4. Discussion 
$1 \sim 12 \mathrm{nmol} / \mathrm{kg} \mathrm{D}-\mathrm{Mn}$ were observed near the Pribilof Islands. Surface D-Fe and D-Mn

2 increased to $\sim 4 \mathrm{nmol} / \mathrm{kg}$ and $\sim 34 \mathrm{nmol} / \mathrm{kg}$, respectively, in the coastal domain. The

3 concentrations of D-M in this work are comparable to these values.

Buck and Bruland (Buck and Bruland, 2007) reported the surface D-Fe concentrations, organic ligand concentrations, and stability constants for the Fe complexes along transects in the southeastern Bering Sea. The concentrations of D-Fe are also consistent with our data. They found that the concentrations of $\mathrm{D}-\mathrm{Fe}$ were strongly correlated with ambient stronger $\mathrm{L}_{1}$ ligand concentrations for all samples with $\mathrm{D}-\mathrm{Fe}$ concentrations greater than $0.2 \mathrm{nmol} / 1$. Since D-Fe did not increase significantly between 6 and 9 years storage in this study, it is unlikely that the effects of ligands on the determination of D-Fe change with storage time.

For total dissolvable species, Heggie et al (Heggie et al., 1987) observed the vertical and cross-shelf distributions of TD-Mn and TD-Cu in the eastern Bering Sea during October 1980. Their seawater samples were not filtered and acidified to $\mathrm{pH} 2$ with $\mathrm{HCl}$. At outer shelf stations close to BR003, the concentrations of TD-Mn were $\sim 8 \mathrm{nmol} / \mathrm{kg}$ in surface water and $\sim 30 \mathrm{nmol} / \mathrm{kg}$ in bottom water with a break at 60-80 $\mathrm{m}$ depth. The concentrations of TD-Cu were $\sim 6 \mathrm{nmol} / \mathrm{kg}$ in surface water and $\sim 4 \mathrm{nmol} / \mathrm{kg}$ in bottom water. These results are generally consistent with our results of TD-Mn and TD-Cu at BR003, where TD-Mn showed a shallower break and higher bottom concentrations, and TD-Cu exhibited a minimum at mid depth and a bottom maximum. Heggie et al. (Heggie et al., 1987) reported that the concentrations of TD-Mn were $13-20 \mathrm{nmol} / \mathrm{kg}$ in the surface layer and $25-40 \mathrm{nmol} / \mathrm{kg}$ in the bottom layer of the middle shelf domain around $\sim 57.5^{\circ} \mathrm{N}, \sim 164^{\circ} \mathrm{W}$. The concentrations of TD-Cu were 4-7 nmol/kg. These values are also comparable with those of our TD-Mn and $\mathrm{TD}-\mathrm{Cu}$.

For particulate species, Hurst and Bruland (Hurst and Bruland, 2007) and Hurst et 
1 al. (Hurst et al., 2010) reported the particulate concentrations of $\mathrm{Al}, \mathrm{Mn}, \mathrm{Fe}$, and $\mathrm{Zn}$ in the

2 southeastern Bering Sea. The leachable particulate metals from filter samples was based 3 upon a weak acid leach $(\mathrm{pH} 2)$ together with a mild reducing agent to access readily reducible

4 Fe oxy-hydroxides and a short heating step to denature proteins and promote the release of 5 bound intracellular metals. The filter and associated refractory particulate material was then 6 microwave-bomb digested for total particulate (TP) metals. At station $13\left(57.7^{\circ} \mathrm{N}\right.$, $7 \quad 168.7^{\circ} \mathrm{W}$ ) in the middle shelf domain, total particulate $\mathrm{Al}, \mathrm{Mn}$, and Fe were $10-40,1-2$, and $8 \quad 5-10 \mathrm{nmol} / \mathrm{l}$ in surface water, respectively. They reached to $290,6.5$, and $130 \mathrm{nmol} / \mathrm{l}$ in bottom 9 water, respectively. The fraction of leachable particulate M in TP-M accounted for $\sim 35 \%$ for $\mathrm{Al}, \sim 95 \%$ for $\mathrm{Mn}$, and $\sim 75 \%$ for $\mathrm{Fe}$. TP-Zn was $\sim 0.5 \mathrm{nmol} / \mathrm{l}$ and leachable particulate $\mathrm{Zn}$ 11 was $\sim 0.1 \mathrm{nmol} / \mathrm{l}$ in a mixed seawater sample prepared from surface and subsurface waters. 12 LP-Al and LP-Zn at BR005 are comparable with these values. LP-Mn and LP-Fe at BR005 13 are, however, 6-17 times higher than the reported TP-Mn and TP-Fe. These results suggest 14 that particulate $\mathrm{Mn}$ and Fe vary considerably with time and space. According to the data of 15 Hurst et al. (Hurst et al., 2010), the fraction of refractory particulate Al was much higher 16 compared to Mn and Fe. These results are consistent with our results that show a significant 17 increase in TD-Al with storage time (Section 3.2).

To the best of our knowledge, there were no published data of $\mathrm{Ni}$ and $\mathrm{Pb}$ in this 19 area

TD-M consists of D-M and LP-M. It has been suggested that organisms can 24 utilize at least some of LP-M (Berger et al., 2008; Kinugasa et al., 2005). Thus, the concentrations of TD-M would be a measure of total bioavailable trace metals. Firstly, the 
1 Bering Sea shelf is characterized by considerably high concentrations of TD-M compared to 2 the North Pacific (Figs. 4 and 6).

The average fraction of LP-M/TD-M throughout the water column was calculated

4 and plotted against latitude in Fig. 8. More than $83 \%$ of TD-Fe is occupied by LP-Fe over 5 the entire area, whereas more than $70 \%$ of TD-Cd is occupied by D-Cd. The other metals

6 are plotted between $\mathrm{Fe}$ and $\mathrm{Cd}$. LP-Al/TD-Al is relatively low in the middle and outer shelf 7 domains. $\mathrm{Mn}, \mathrm{Co}, \mathrm{Zn}$, and $\mathrm{Pb}$ have a similar distribution of the LP-M/TD-M ratio. Ni and $8 \mathrm{Cu}$ show another type of distribution. The LP-M/TD-M ratios are usually less than $10 \%$ for $9 \mathrm{Ni}, \mathrm{Cu}, \mathrm{Zn}$, and $\mathrm{Cd}$ in the North Pacific (Ezoe et al., 2004). Thus the generally high

\subsection{Input of bioactive trace metals from the Yukon River}

Our data show that the Yukon River is a significant source of bioactive trace metals in the coastal domain. The river plume is clearly observed on the sectional distributions of TD-M and LP-M (except Cd; Figs. 6 and 7). It is difficult to explain such high concentrations by the other mechanisms. It should be noted that the river plume is obvious for D-Al, D-Ni, and D-Cu, while it is not so obvious for the other D-M (Fig. 5). The concentrations of trace elements in river water were measured during the 
1 synoptic sampling cruises in the Yukon River basin in years 2002 and 2003 by the U.S.

2 Geological Survey (Dornblaser and Halm, 2006). River water samples were collected using

3 an Equal Discharge Increment and filtered through a $0.45 \mu \mathrm{m}$ filter. The concentrations of

4 D-M at the Yukon River near Kaltag in June 2003 were as follows: $0.14 \mu \mathrm{mol} / \mathrm{kg}$ for Mn, 3.7

$5 \mu \mathrm{mol} / \mathrm{kg}$ for Fe, $1.4 \mathrm{nmol} / \mathrm{kg}$ for $\mathrm{Co}, 29 \mathrm{nmol} / \mathrm{kg}$ for $\mathrm{Ni}, 58 \mathrm{nmol} / \mathrm{kg}$ for $\mathrm{Cu}, 0.11 \mathrm{nmol} / \mathrm{kg}$ for

$6 \mathrm{Cd}$, and $0.82 \mathrm{nmol} / \mathrm{kg}$ for $\mathrm{Pb}$. $\mathrm{S}$ was $\sim 32$ over the shelf and 30.22 at BR012 $\left(63.5^{\circ} \mathrm{N}\right)$,

7 suggesting that a contribution of river water was $5.6 \%$ at this station. Assuming the same

8 dilution factor for D-M, input from river water would account for $52 \%$ of D-Mn, $2300 \%$ of

9 D-Fe, $27 \%$ of D-Co, $22 \%$ of $\mathrm{D}-\mathrm{Ni}, 40 \%$ of $\mathrm{D}-\mathrm{Cu}, 1.4 \%$ of $\mathrm{D}-\mathrm{Cd}$, and $91 \%$ of $\mathrm{D}-\mathrm{Pb}$. Thus,

10 the input from river water is actually significant for D-M except D-Cd. It is probable that

11 most dissolved $\mathrm{Mn}, \mathrm{Fe}, \mathrm{Co}$, and $\mathrm{Pb}$ from the Yukon River has been transformed into

12 particulate species before reaching BR012. The sectional distributions of D-M suggest that

13 sedimentary reduction processes in the coastal domain are a more significant source for D-Mn 14 and D-Co. Deep waters in the outer and middle shelf domain are a more significant source for D-Zn and D-Cd. It seems that these three sources give comparable contribution to D-Fe and little contribution to $\mathrm{D}-\mathrm{Pb}$.

The input of D-M from the Yukon River also would account for $2.7 \%$ of TD-Mn, $1.8 \%$ of TD-Fe and $\mathrm{Co}, 7.0 \%$ of TD-Ni, $17 \%$ of TD-Cu, $1.1 \%$ of TD-Cd, and $3.8 \%$ of TD-Pb at BR012. These percentages seem to be low to explain the dominance of riverine supply on the distributions of TD-M except TD-Cd. There must be larger supplies of LP-M from the Yukon River. It is interesting that the concentrations of TD-M and LP-M at BR013 $\left(64.0^{\circ} \mathrm{N}\right)$ are mostly comparable with those at BR010 $\left(62.0^{\circ} \mathrm{N}\right)$. The effect of the river plume disappears at BR013. Further observations are necessary to address the nature of the river plume and to quantify the budget of bioactive trace metals on the Bering Sea shelf. 


\subsection{Stoichiometry of dissolved bioactive trace metals}

Dissolved inorganic nitrogen (DIN), which is the sum of nitrate, nitrite, and ammonium, is plotted against phosphate in Fig. 9 (a) for all samples of this study. The regression line for the data of BR003, at the boundary between the outer and middle shelf domains, is given by the following equation:

$$
\mathrm{DIN}[\mu \mathrm{mol} / \mathrm{kg}]=15.3 * \mathrm{PO}_{4}[\mu \mathrm{mol} / \mathrm{kg}]-5.1 \quad\left(r^{2}=1.00, n=11 \quad\right)
$$

The results suggest that $\mathrm{N}$ and $\mathrm{P}$ follow the stoichiometry of Redfield ratios at BR003, while $\mathrm{N}$ depletes earlier than $\mathrm{P}$. All other data are plotted on the right side of this line. This means there is a substantial additional supply for P on the Bering Sea shelf. Silicate vs. DIN for all data gives the following regression line (the figure is not shown):

$$
\mathrm{DIN}[\mu \mathrm{mol} / \mathrm{kg}]=0.670 * \mathrm{Si}(\mathrm{OH})_{4}[\mu \mathrm{mol} / \mathrm{kg}]-3.1 \quad\left(r^{2}=0.97, n=54\right)
$$

These results suggest that $\mathrm{N}$ is the limiting element for organisms in this area.

DIN is plotted against D-Fe in Fig. 9 (b) for all data of this study. The regression line for nitrate vs. D-Fe observed in the oceanic domain of the Bering Sea $\left(57.6^{\circ} \mathrm{N}, 179.9^{\circ} \mathrm{E}\right.$; (Fujishima et al., 2001)) is shown for comparison. The positive intercept on the y axis suggests that $\mathrm{D}-\mathrm{Fe}$ is relatively depleted. Actually, iron limitation in the oceanic domain has been ascertained by shipboard incubations (Leblanc et al., 2005; Peers et al., 2005) and by underway fast repetition-rate fluorometer measurements (Suzuki et al., 2002). All data from the Bering Sea shelf are plotted on the right side of the line. These results suggest that this area is rich with D-Fe compared to N. Similar results are observed for D-Mn, D-Ni, and D-Zn (the figures are not shown).

D-Cd is plotted against phosphate in Fig. 9 (c), where the regression line observed in the Green Belt $\left(56.3^{\circ} \mathrm{N}, 171.6^{\circ} \mathrm{E}\right.$; (Cullen, 2006)) is shown for comparison. Most data from the Bering Sea shelf are plotted above the line. The Cd:P ratio from the two Bering Sea stations have been reported (Cullen, 2006). At the HNLC-Fe limited station $\left(55^{\circ} \mathrm{N}\right.$, 
$1 \quad 179 \cdot \mathrm{W})$, the $\mathrm{Cd}: \mathrm{P}$ ratio was $0.17 \pm 0.01 \mathrm{nmol}^{\mathrm{mmol}}{ }^{-1}$ in surface water and $0.33 \pm 0.04 \mathrm{nmol}$

$2 \mathrm{mmol}^{-1}$ below the mixed layer. At the Green Belt station, the Cd:P ratio was $0.33 \pm 0.02$

$3 \mathrm{nmol} \mu \mathrm{mol}^{-1}$ in the upper $75 \mathrm{~m}$ and $0.36 \pm 0.02 \mathrm{nmol} \mu \mathrm{mol}^{-1}$ below the mixed layer. At

4 BR003, the Cd:P ratio is $0.53 \pm 0.06 \mathrm{nmol}_{\mu} \mathrm{mol}^{-1}$ in the upper $40 \mathrm{~m}$ and $0.37 \pm 0.08 \mathrm{nmol}$

$5 \quad \mathrm{mmol}^{-1}$ below the mixed layer. The Cd:P ratio further increases at the other stations in this 6 study.

All these results indicate that D-M is plentiful over the Bering Sea shelf compared with macronutrients. In addition, there are considerable amounts of LP-M. Thus, the bioactive trace metals should not have been limiting factors for the growth of phytoplankton, even when massive blooming of Emiliania huxleyi occurred.

The logarithms of D-M/phosphate and nutrient/phosphate are calculated for deep water in each domain and plotted in Fig. 10. For comparison, the data for the SAFe D2 reference material $\left(30^{\circ} \mathrm{N}, 140^{\circ} \mathrm{W} ; 2000 \mathrm{~m}\right.$ depth) from the North Pacific Ocean are also plotted (Sohrin et al., 2008). The N/P ratio decreases with the flow of ACW due to sedimentary denitrification (Koike and Hattori, 1979; Tanaka et al., 2004). The Si/P ratio is lowest in the North Pacific and highest in the outer shelf domain. The D-M/P ratios show different variations from N/P and $\mathrm{Si} / \mathrm{P}$. It is apparent that the Bering Shelf is enriched with $\mathrm{Co}$ and $\mathrm{Pb}$ and depleted with $\mathrm{Ni}, \mathrm{Cu}, \mathrm{Zn}$, and $\mathrm{Cd}$ compared with the North Pacific. The major reasons should be as follows: (1) the North Pacific deep water is enriched with $\mathrm{Ni}, \mathrm{Cu}$, Zn, and $\mathrm{Cd}$ by remineralization and depleted with $\mathrm{Co}$ and $\mathrm{Pb}$ by scavenging; (2) surface water, which has the depleted concentrations of $\mathrm{Ni}, \mathrm{Cu}, \mathrm{Zn}$, and $\mathrm{Cd}$ by uptake of phytoplankton and the elevated concentrations of $\mathrm{Co}$ and $\mathrm{Pb}$ by lithogenic and anthropogenic input, contributes to the formation of deep water on the Bering Sea shelf; (3) there is preferential supply of $\mathrm{P}$ over $\mathrm{Ni}, \mathrm{Cu}, \mathrm{Zn}$, and $\mathrm{Cd}$ on the Bering Sea shelf. The dissolved elemental composition of $\mathrm{P}: \mathrm{N}: \mathrm{Si}: \mathrm{Al}: \mathrm{Mn}: \mathrm{Fe}: \mathrm{Co}: \mathrm{Ni}: \mathrm{Cu}: \mathrm{Zn}: \mathrm{Cd}: \mathrm{Pb}$ at the boundary between the outer and 
1 middle shelf domains is $1: 11.4: 22.8: 1.6 \times 10^{-3}: 9.6 \times 10^{-3}: 4.6 \times 10^{-3}: 9.7 \times 10^{-5}: 2.9 \times 10^{-3}$ :

$21.4 \times 10^{-3}: 4.0 \times 10^{-3}: 3.2 \times 10^{-4}: 1.5 \times 10^{-5}$. The composition is $1: 7.8 \times 10^{-2}: 11.4: 1.3 \times 10^{-2}$ :

$3 \quad 3.2 \times 10^{-2}: 1.1 \times 10^{-2}: 6.8 \times 10^{-4}: 8.1 \times 10^{-3}: 6.1 \times 10^{-3}: 1.1 \times 10^{-2}: 6.6 \times 10^{-4}: 7.8 \times 10^{-5}$ at BR013

4 near the Bering Strait. The latter ratios are 2-8 times higher than the former ratios for each

5 D-M. It is possible that BSW had higher ratios and increased the ratios at BR013 by mixing

6 with ACW. Since $\mathrm{N}$ is most depleted near the Bering Strait, processes under reducing

7 conditions may be involved for producing the high ratios. In this way, the stoichiometry of

8 D-M is significantly altered in the Bering Sea. The seawater flowing into the Arctic Ocean

9 through the Bering Strait will have a stoichiometry of D-M distinct from that of the North

10 Pacific deep water.

12 4.5. Nature of labile particulate bioactive trace metals

13 To evaluate the nature of LP-M, the enrichment factor (EF) was calculated by 14 normalizing the $\mathrm{LP}-\mathrm{M} / \mathrm{LP}-\mathrm{Al}$ ratio with the $\mathrm{M} / \mathrm{Al}$ ratio in the crust:

$$
\mathrm{EF}=(\mathrm{LP}-\mathrm{M} / \mathrm{LP}-\mathrm{Al})_{\text {Bering Sea }} /(\mathrm{M} / \mathrm{Al})_{\text {crust }}
$$

16 The composition of the upper crust (Rudnick and Gao, 2005) was used to calculate the crustal 17 ratio. $\mathrm{Al}$ was used as the reference element, because it is abundant in terrestrially derived 18 aluminosilicate clays and relatively unreactive in seawater that makes it a reliable indicator of 19 the contribution of the crust-derived particulate materials. The average log EF throughout 20 the water column for each station is plotted against latitude in Fig. 11. A major feature is 21 that the EF is higher than 6 for all the elements. This means a small contribution of 22 terrigenous aluminosilicates to LP-M except LP-Al. LP-Cd shows the highest EF over the 23 whole area. The $\mathrm{EF}$ for $\mathrm{Cd}, \mathrm{Cu}, \mathrm{Zn}$, and $\mathrm{Ni}$ is relatively high in the outer and middle shelf 24 domains. It should be noted that the present EF is based on the labile particulate 25 concentrations. The high EF values are partly due to fact that only a small percentage of 
1 particulate $\mathrm{Al}$ is labile. Also the distribution of EF may be affected by the formation of

2 labile-amorphous $\mathrm{Al}$ hydroxides from the precipitation of soluble $\mathrm{Al}$ in river runoff.

LP-M can be assumed to be composed of three fractions: (1) terrigenous

4 aluminosilicates; (2) hydrogenous and biogenic inorganic matter, such as Fe-Mn oxides and

5 Ca carbonates; (3) biogenic organic matter. Using the average LP-M concentrations over the

6 Bering Sea shelf, we have estimated the percent composition of these fractions. We firstly

7 estimated the aluminosilicate fraction for each element assuming that this fraction accounts

8 for $100 \%$ of LP-Al and is proportional to the product of the LP-Al concentration and the

$9 \mathrm{M} / \mathrm{Al}_{\text {crust }}$ ratio for the other elements. The aluminosilicate fraction was $0.16 \%$ for LP-Cd.

10 Taking account of the correlation between LP-Cd and Chl. $a(r=0.68)$, we assumed that

11 LP-Cd consists of $80 \%$ of the organic fraction and $20 \%$ of the oxide fraction, and calculated

12 the organic fraction of the other LP-M using the LP-Cd concentration and the average 13 elemental composition proposed for marine phytoplankton (Li, 2000). Finally, we attributed

14 the remaining percentage to the oxide fraction. The estimated average compositions of

15 LP-M are given in Fig. 12. This estimation did not work well for LP- $\mathrm{Zn}$ and LP-Pb because

16 of high concentrations of these elements in phytoplankton in the literature. Figure 12

17 indicates that LP-Mn, LP-Fe, and LP-Co are dominated by the oxide fraction. The organic

18 fractions account for higher percentages for LP-Ni and LP-Cu. These conclusions does not 19 change significantly even when we slightly decrease the terrigenous fraction for LP-Al and/or 20 the organic fraction for LP-Cd. Thus, it can be concluded that the oxide fraction is major for 21 labile particulate $\mathrm{Mn}, \mathrm{Fe}, \mathrm{Co}, \mathrm{Ni}$, and $\mathrm{Cu}$. Formation of Fe-Mn oxides and adsorption of 22 trace metals on the oxides will be responsible for these results.

24 5. Conclusions

Seawater on the Bering Sea shelf was metalliferous. LP-M comprised larger 
1 fractions in TD-M compared with the North Pacific. LP-Al and LP-Cd were dominated by

2 terrigenous clay and organic matter, respectively, while labile particulate $\mathrm{Mn}, \mathrm{Fe}, \mathrm{Co}, \mathrm{Ni}$, and

$3 \mathrm{Cu}$ were dominated by Fe-Mn oxides. D-M was abundant compared to macronutrients even

4 during massive blooming of Emiliania huxleyi, suggesting there was no trace metal limitation

5 on the growth of organisms. Mn reduction occurred in the sediments of the coastal domain,

6 resulting in concurrent increase of $\mathrm{D}-\mathrm{Mn}$ and $\mathrm{D}-\mathrm{Co}$ in the water column. It seems Fe

7 reduction also occurred in the sediments. Relative to phosphate, the Bering Seas shelf was

8 enriched with D-Co and D-Pb and depleted with D-Ni, D-Cu, D-Zn, and D-Cd compared with

9 the North Pacific. The stoichiometry of D-M was further modified with the flow of ACW.

11 Acknowledgements

12 A.P.C. was supported by Monbukagakusho (MEXT) scholarship. We are grateful 13 to Captain Masaharu Akamine and the crew of R/V Mirai (JAMSTEC) during the MR00-K06 14 cruise. We thank the chief scientist Dr. Takatoshi Takizawa, Prof. Noriyuki Tanaka, and 15 onboard scientists and technicians. Basic oceanographic parameters were obtained thanks to 16 staffs from JAMSTEC and Nippon Marine Enterprises. This research was partly supported 17 by funds from the Steel Industry Foundation for the advancement of Environmental 18 Protection Technology and from Grant-in-Aid of Scientific Research, the Ministry of 19 Education, Culture, Sports, Science, and Technology of Japan. 
$1 \quad$ Figure captions

2 Figure 1. Sampling locations on the Bering Sea shelf.

3 Figure 2. Sectional distributions of oceanographic parameters over the Bering Sea shelf.

4 Figure 3. Concentrations of (a) TD-Al and (b) D-Al determined after storage of 6 y (closed 5 diamonds) and 9 y (open squares).

6 Figure 4. Vertical profiles of TD-M (closed circles) and D-M (open circles) at BR003. The

$7 \mathrm{H}$ shaped bars at the bottom of each panel show the typical concentration ranges of D-M in 8 the North Pacific Ocean (Nozaki, 2001).

9 Figure 5. Sectional distributions of D-M over the Bering Sea shelf.

10 Figure 6. Sectional distributions of TD-M over the Bering Sea shelf.

11 Figure 7. Sectional distributions of LP-M over the Bering Sea shelf.

12 Figure 8. Latitudinal distribution of the LP-M/TD-M ratio.

13 Figure 9. Property vs. property plots for macronutrients and D-M. (a) phosphate vs. DIN.

14 The regression line is for BR003 (see text). (b) D-Fe vs. DIN. The regression line was 15 obtained from the data at $57.6^{\circ} \mathrm{N}, 179.9^{\circ} \mathrm{E}$ in the oceanic domain of the Bering Sea (Fujishima 16 et al., 2001). (c) phosphate vs. D-Cd. The regression line was obtained from the data at $1756.3^{\circ} \mathrm{N}, 171.6^{\circ} \mathrm{E}$ in the Green Belt (Cullen, 2006).

18 Figure 10. Stoichiometry of (a) D-M and (b) macronutrients. The concentrations of D-M 19 and macronutrients were normalized against those of phosphate. The Pacific deep water 20 data were taken from the SAFe D2 reference material $\left(30^{\circ} \mathrm{N}, 140^{\circ} \mathrm{W} ; 2000 \mathrm{~m}\right.$ depth; (Sohrin 21 et al., 2008)).

22 Figure 11. Latitudinal distribution of logarithms of the enrichment factor (LP-M/LP-Al) Bering $23 \mathrm{Sea} /(\mathrm{M} / \mathrm{Al})_{\text {crust }}$.

24 Figure 12. Average composition of LP-M over the Bering Sea shelf. Estimation of oxide 25 and organic fractions was impossible for $\mathrm{Zn}$ and $\mathrm{Pb}$ (see text). 
1 References

2 Aguilar-Islas AM, Hurst MP, Buck KN, Sohst B, Smith GJ, Lohan MC and Bruland KW (2007) Micro- and macronutrients in the southeastern Bering Sea: Insight into iron-replete and iron-depleted regimes. Progr Oceanogr, 73: 99-126.

Berger CJM, Lippiatt SM, Lawrence MG and Bruland KW (2008) Application of a chemical leach technique for estimating labile particulate aluminum, iron, and manganese in the Columbia River plume and coastal waters off Oregon and Washington. J Geophys Res, 113: C00B01. doi: 10.1029/2007jc004703

Brown MT and Bruland KW (2008) An improved flow-injection analysis method for the determination of dissolved aluminum in seawater. Limnol Oceanogr: Methods, 6: $87-95$.

Buck KN and Bruland KW (2007) The physicochemical speciation of dissolved iron in the Bering Sea, Alaska. Limnol Oceanogr, 52: 1800-1808.

Coachman LK (1986) Circulation, water masses, and fluxes on the southeastern Bering Sea shelf. Cont Shelf Res, 5: 23-108.

Cullen JT (2006) On the nonlinear relationship between dissolved cadmium and phosphate in the modern global ocean: Could chronic iron limitation of phytoplankton growth cause the kink? Limnol Oceanogr, 51: 1369-1380.

Dornblaser MM and Halm DR, 2006. Water and Sediment Quality of the Yukon River and its Tributaries, from Eagle to St. Marys, Alaska, 2002-2003, U.S. Geological Survey Open-File Report 2006-1228.

Ezoe M, Ishita T, Kinugasa M, Lai X, Norisuye K and Sohrin Y (2004) Distribution of dissolved and acid-dissolvable bioactive trace metals in the North Pacific Ocean. Geochem J, 38: 535-550.

Fujishima Y, Ueda K, Maruo M, Nakayama E, Tokutome C, Hasegawa H, Matsui M and 
Sohrin Y (2001) Distribution of Trace Bioelements in the Subarctic North Pacific Ocean and the Bering Sea (the R/V Hakuho-Maru Cruise KH-97-2). J Oceanogr, 57: 261-273.

Grebmeier JM, Cooper LW, Feder HM and Sirenko BI (2006a) Ecosystem dynamics of the Pacific-influenced Northern Bering and Chukchi Seas in the Amerasian Arctic. Progr Oceanogr, 71: 331-361.

Grebmeier JM, Overland JE, Moore SE, Farley EV, Carmack EC, Cooper LW, Frey KE, Helle JH, McLaughlin FA and McNutt SL (2006b) A Major Ecosystem Shift in the Northern Bering Sea. Science, 311: 1461-1464.

Heggie D, Klinkhammer G and Cullen D (1987) Manganese and copper fluxes from continental margin sediments. Geochim Cosmochim Acta, 51: 1059-1070.

Heggie DT (1982) Copper in surface waters of the Bering Sea. Geochim Cosmochim Acta, 46: 1301-1306.

Holmes RM, McClelland JW, Peterson BJ, Shiklomanov IA, Shiklomanov AI, Zhulidov AV, Gordeev VV and Bobrovitskaya NN (2002) A circumpolar perspective on fluvial sediment flux to the Arctic ocean. Global Biogeochem Cycles, 16: 1098. doi: $10.1029 / 2001 \mathrm{gb} 001849$

Hurst MP, Aguilar-Islas AM and Bruland KW (2010) Iron in the southeastern Bering Sea: Elevated leachable particulate Fe in shelf bottom waters as an important source for surface waters. Cont Shelf Res, 30: 467-480.

Hurst MP and Bruland KW (2007) An investigation into the exchange of iron and zinc between soluble, colloidal, and particulate size-fractions in shelf waters using low-abundance isotopes as tracers in shipboard incubation experiments. Mar Chem, 103: $211-226$.

Kachel NB, Hunt GL, Salo SA, Schumacher JD, Stabeno PJ and Whitledge TE (2002) 
3 Kinugasa M, Ishita T, Sohrin Y, Okamura K, Takeda S, Nishioka J and Tsuda A (2005)

Characteristics and variability of the inner front of the southeastern Bering Sea. Deep-Sea Res II, 49: 5889-5909. Dynamics of trace metals during the subarctic Pacific iron experiment for ecosystem dynamics study (SEEDS2001). Progr Oceanogr, 64: 129-147.

Koike I and Hattori A (1979) Estimates of denitrification in sediments of the Bering Sea shelf. Deep-Sea Res A, 26: 409-415.

Leblanc K, Hare CE, Boyd PW, Bruland KW, Sohst B, Pickmere S, Lohan MC, Buck K, Ellwood MJ and Hutchins DA (2005) Fe and Zn effects on the Si cycle and diatom community structure in two contrasting high and low-silicate HNLC areas. Deep-Sea Res I, 52: 1842-1864.

Li Y-H (2000) A Compendium of Geochemistry. Princeton University Press, Princeton, pp 475.

Merico A, Tyrrell T, Lessard EJ, Oguz T, Stabeno PJ, Zeeman SI and Whitledge TE (2004) Modelling phytoplankton succession on the Bering Sea shelf: role of climate influences and trophic interactions in generating Emiliania huxleyi blooms 1997-2000. Deep-Sea Res I, 51: 1803-1826.

Moffett JW and Ho J (1996) Oxidation of cobalt and manganese in seawater via a common microbially catalyzed pathway. Geochim Cosmochim Acta, 60: 3415-3424.

Nozaki Y (2001) Elemental Distribution. In: Steele JH, Thorpe SA and Turekian KK (eds) Encyclopedia of Ocean Sciences, 2, Academic Press, San Diego, pp. 840-845.

Okkonen SR, Schmidt GM, Cokelet ED and Stabeno PJ (2004) Satellite and hydrographic observations of the Bering Sea 'Green Belt'. Deep-Sea Res II, 51: 1033-1051.

Peers G, Quesnel S-A and Price NM (2005) Copper requirements for iron acquisition and growth of coastal and oceanic diatoms. Limnol Oceanogr, 50: 1149-1158. 
1 Rho T and Whitledge TE (2007) Characteristics of seasonal and spatial variations of primary 2 production over the southeastern Bering Sea shelf. Cont Shelf Res, 27: 2556-2569.

3 Rudnick RL and Gao S (2005) Composition of the continental crust. In: Rudnick RL (eds) The Crust, Elsevier-Pergamon, Oxford, pp. 1-64.

Saito MA and Moffett JW (2002) Temporal and spatial variability of cobalt in the Atlantic Ocean. Geochim Cosmochim Acta, 66: 1943-1953.

Sigler MF, Harvey HR, Ashjian CJ, Lomas MW, Napp JM, Stabeno PJ and Pelt TIV (2010) How Does Climate Change Affect the Bering Sea Ecosystem? EOS, 91: 457-458.

Sohrin Y, Urushihara S, Nakatsuka S, Kono T, Higo E, Minami T, Norisuye K and Umetani S (2008) Multielemental Determination of GEOTRACES Key Trace Metals in Seawater by ICP-MS after Preconcentration Using an Ethylenediaminetriacetic Acid Chelating Resin. Anal Chem, 80: 6267-6273.

Springer AM, McRoy CP and Flint MV (1996) The Bering Sea Green Belt: shelf-edge processes and ecosystem production. Fish Oceanogr, 5: 205-223.

Stabeno PJ, Bond NA, Kachel NB, Salo SA and Schumacher JD (2001) On the temporal variability of the physical environment over the south-eastern Bering Sea. Fish Oceanogr, 10: 81-98.

Stabeno PJ, Bond NA and Salo SA (2007) On the recent warming of the southeastern Bering Sea shelf. Deep-Sea Res II, 54: 2599-2618.

Suzuki K, Liu H, Saino T, Obata H, Takano M, Okamura K, Sohrin Y and Fujishima Y (2002) East-west gradients in the photosynthetic potential of phytoplankton and iron concentration in the subarctic Pacific Ocean during early summer. Limnol Oceanogr, 47: 1581-1594.

Tanaka T, Guo LD, Deal C, Tanaka N, Whitledge T and Murata A (2004) N deficiency in a well-oxygenated cold bottom water over the Bering Sea shelf: influence of 
sedimentary denitrification. Cont Shelf Res, 24: 1271-1283.

1

2 Tebo BM, Nealson KH, Emerson S and Jacobs L (1984) Microbial mediation of Mn(II) and $\mathrm{Co}(\mathrm{II})$ precipitation at the $\mathrm{O} 2 / \mathrm{H} 2$ interfaces in two anoxic fjords. Limnol Oceanogr, 29: $1247-1258$.

5 Walsh JJ, McRoy CP, Coachman LK, Goering JJ, Nihoul JJ, Whitledge TE, Blackburn TH,

6 Parker PL, Wirick CD, Shuert PG, Grebmeier JM, Springer AM, Tripp RD, Hansell DA, Djenidi S, Deleersnijder E, Henriksen K, Lund BA, Andersen P, Müller-Karger FE and Dean K (1989) Carbon and nitrogen cycling within the Bering/Chukchi Seas: Source regions for organic matter effecting AOU demands of the Arctic Ocean. Progr Oceanogr, 22: 277-359.

Zhang J-Z, Guo L and Fischer C (2010) Abundance and Chemical Speciation of Phosphorus in Sediments of the Mackenzie River Delta, the Chukchi Sea and the Bering Sea: Importance of Detrital Apatite. Aquat Geochem, 16: 353-371-371. 


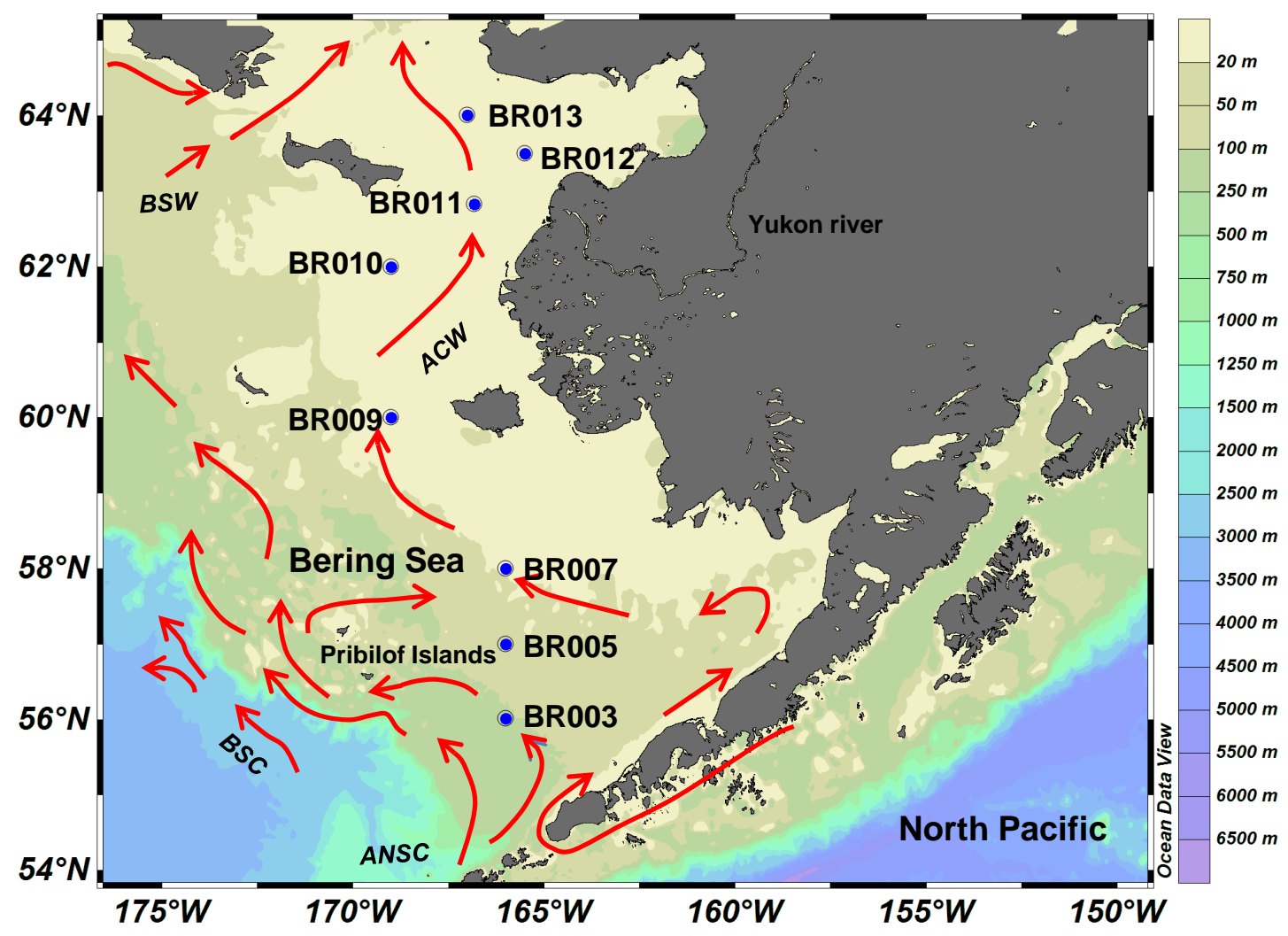

Fig. 1 
Temperature $\left[{ }^{\circ} \mathrm{C}\right]$

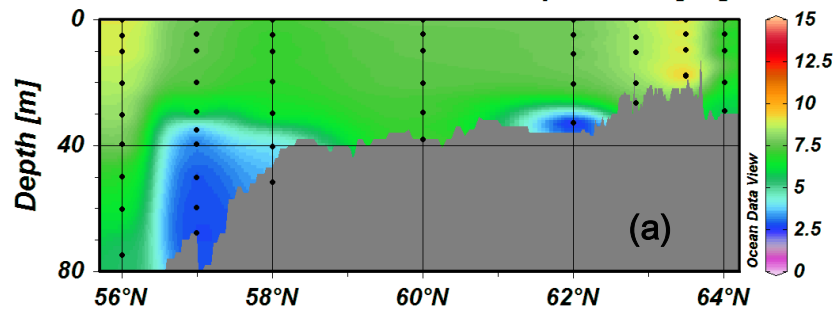

Sigma-0 $\left[\mathrm{kg} / \mathrm{m}^{3}\right]$

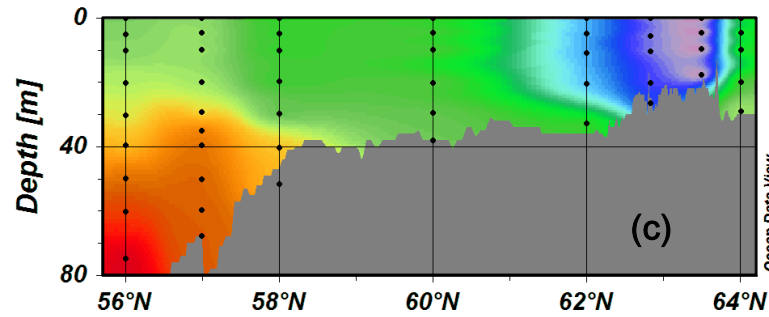

$\mathrm{NO}_{2}[\mu \mathrm{mol} / \mathrm{kg}]$

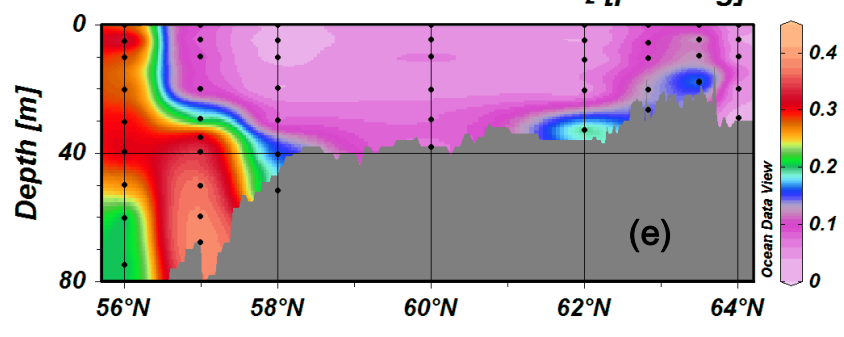

$\mathrm{Si}(\mathrm{OH})_{4}[\mu \mathrm{mol} / \mathrm{kg}]$

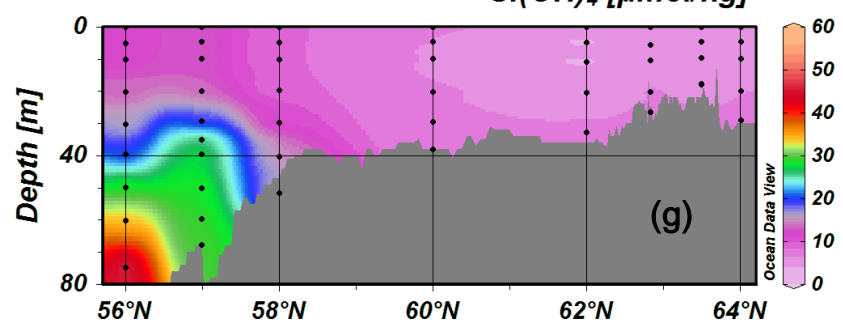

Chl. a $[\mu \mathrm{g} / \mathrm{kg}]$

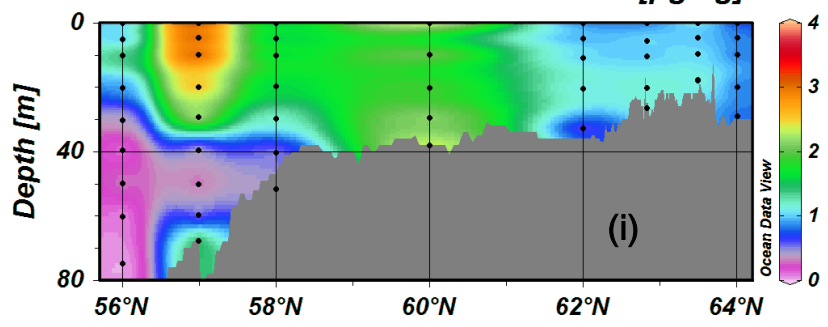

Salinity

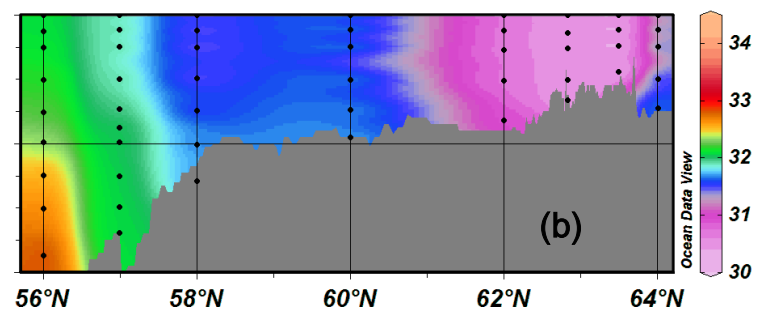

$\mathrm{NO}_{3}[\mu \mathrm{mol} / \mathrm{kg}]$

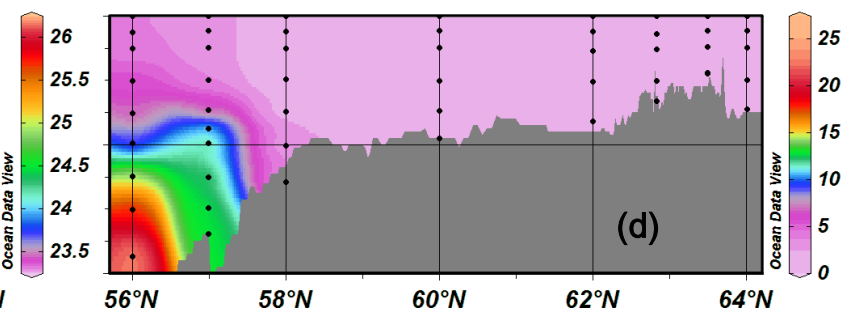

$\mathrm{NH}_{4}[\mu \mathrm{mol} / \mathrm{kg}]$

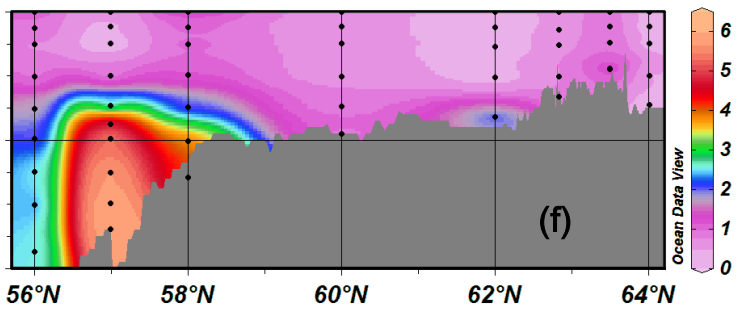

$\mathrm{PO}_{4}[\mu \mathrm{mol} / \mathrm{kg}]$

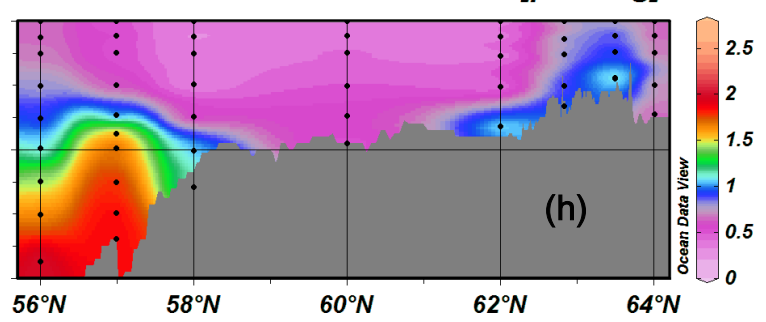

$\mathrm{O}_{2}[\mu \mathrm{mol} / \mathrm{kg}]$

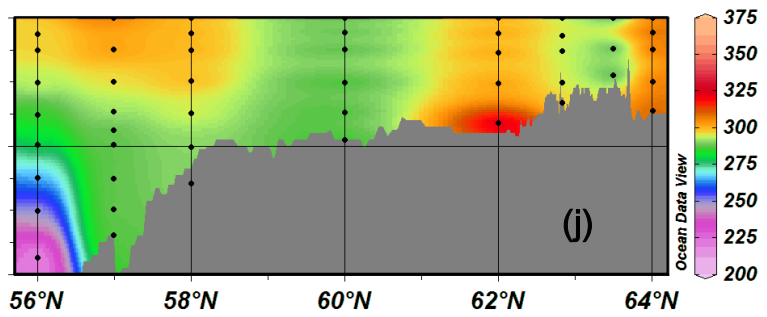

Fig. 2 


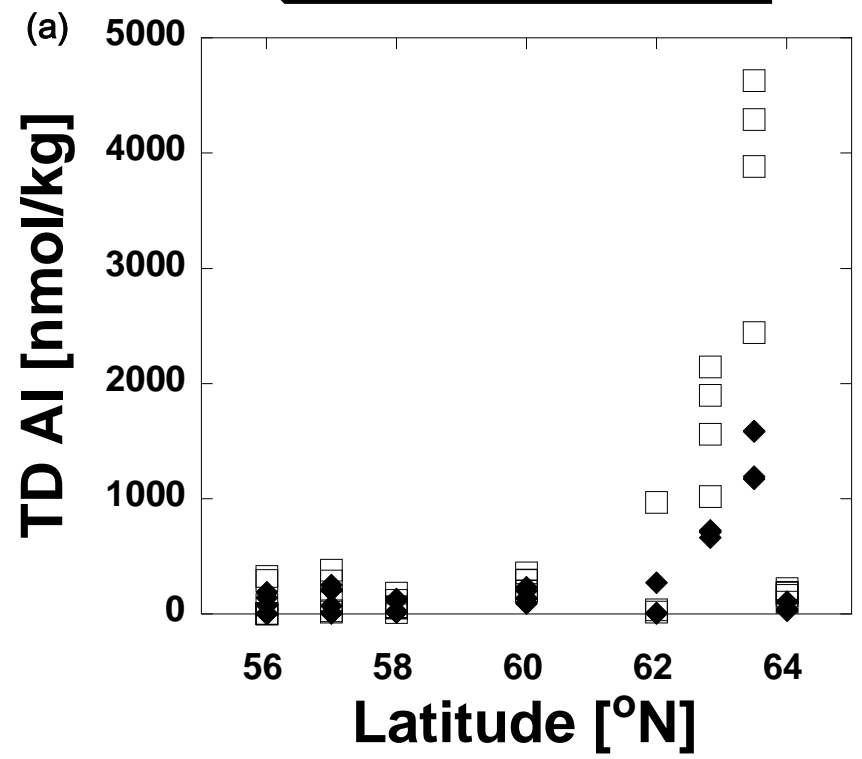

(b)

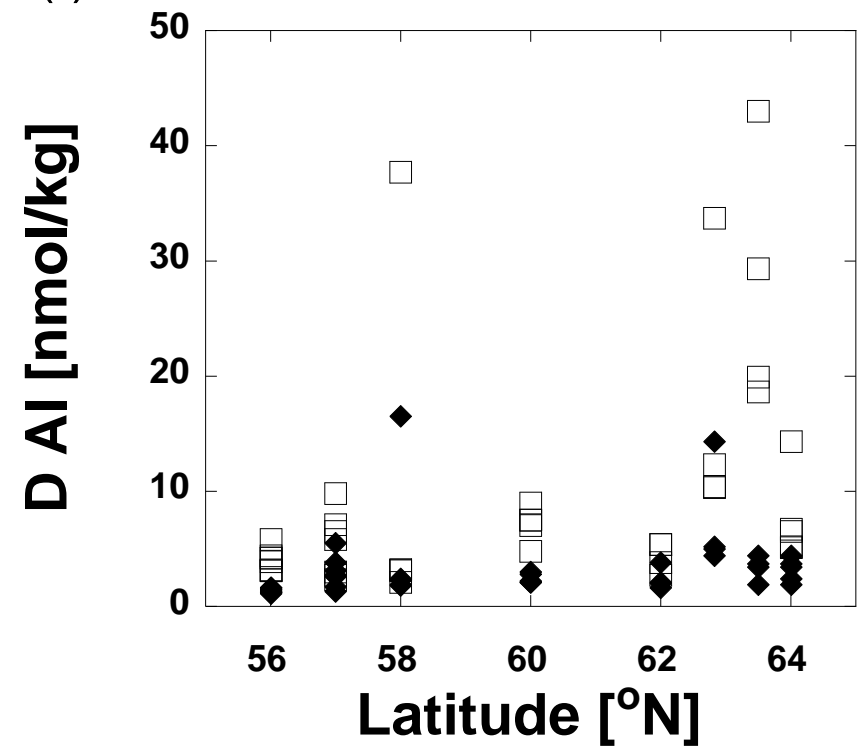

Fig. 3 


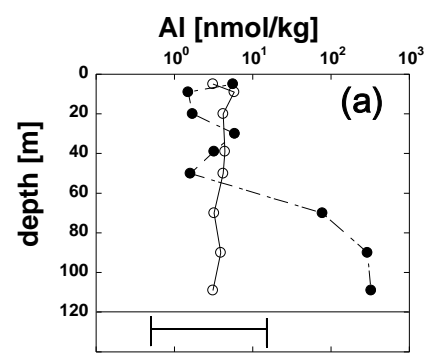

Mn [nmol $/ \mathrm{kg}]$

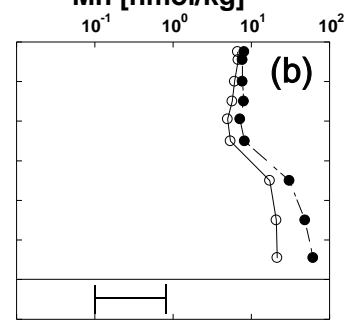

$\mathrm{Fe}[\mathrm{nmol} / \mathrm{kg}]$
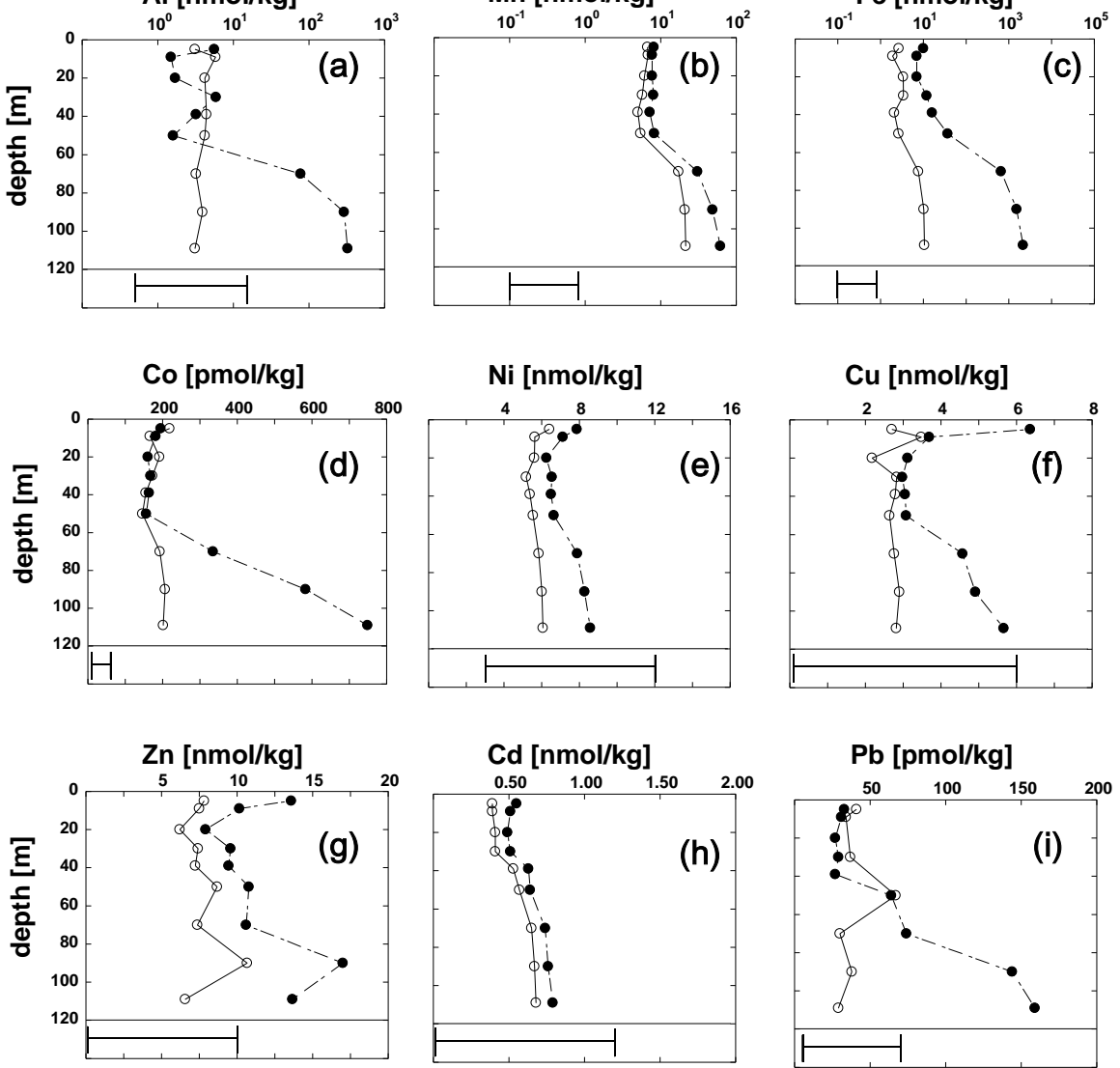

Fig. 4 

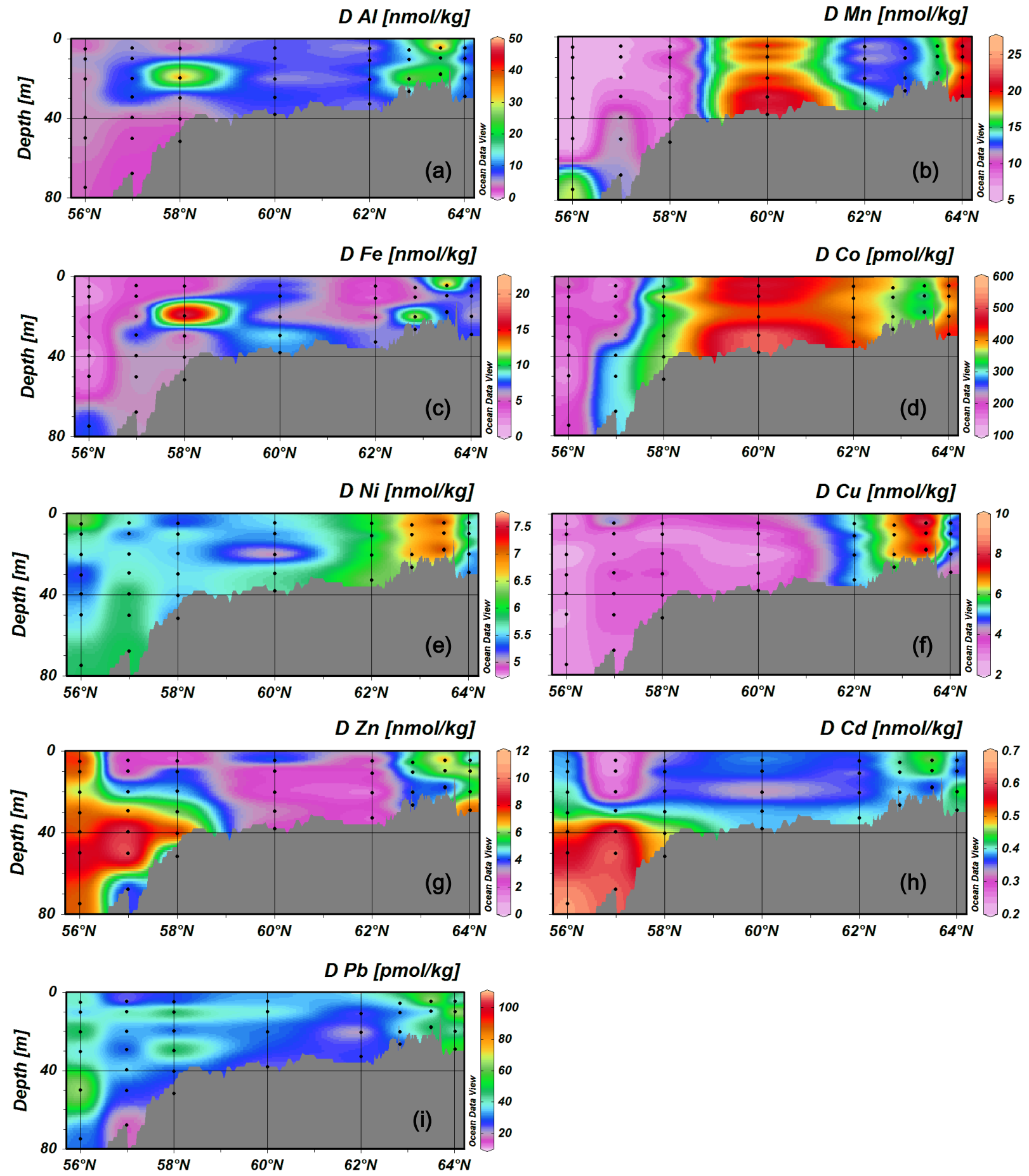

Fig. 5 

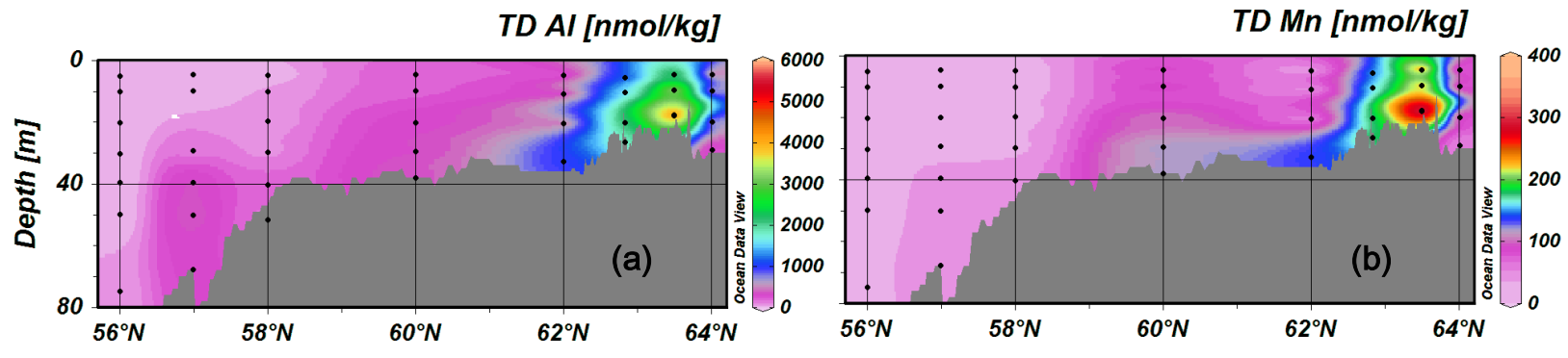

TD Fe [nmol/kg]

$T D$ Co $[\mathrm{pmol} / \mathrm{kg}]$
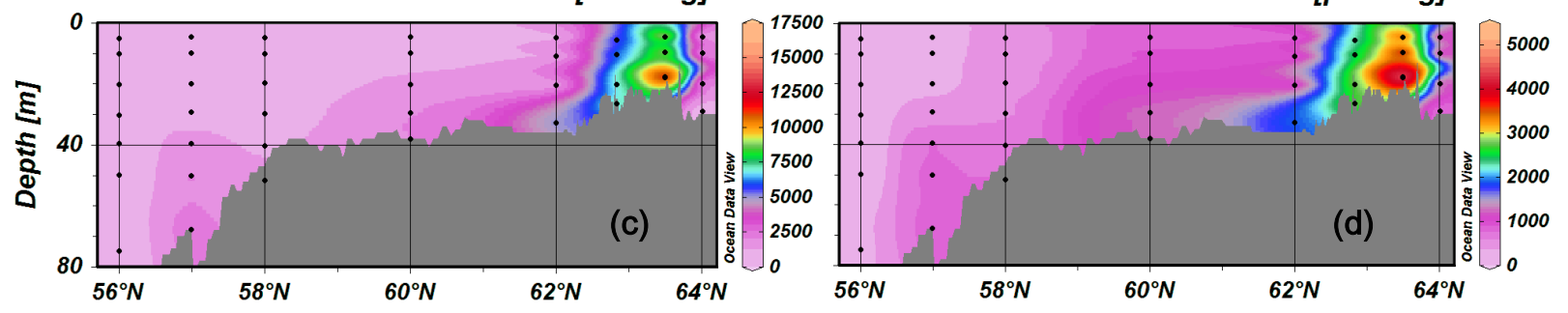

TD Ni [nmol/kg]
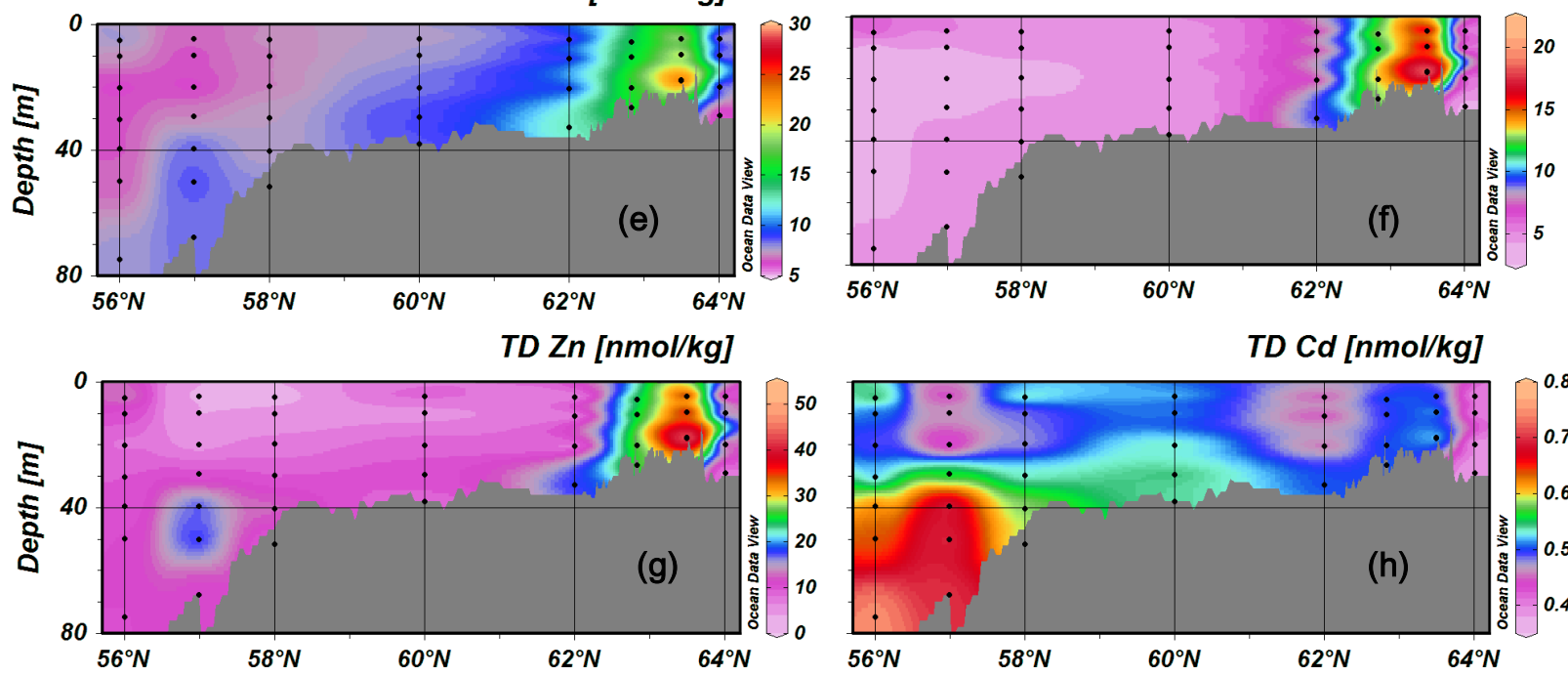

TD Cu [nmol/kg]

TD Cd [nmol/kg]

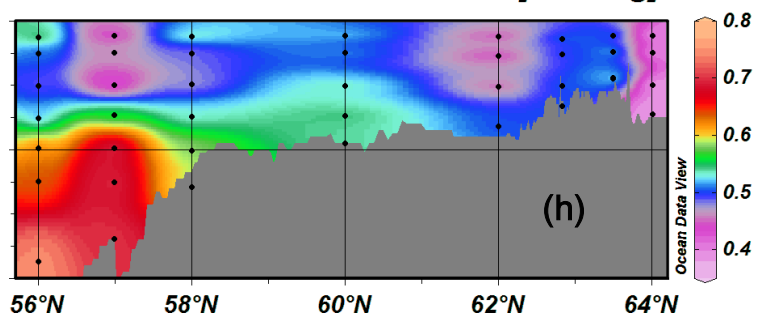

$T D P b[p m o l / k g]$

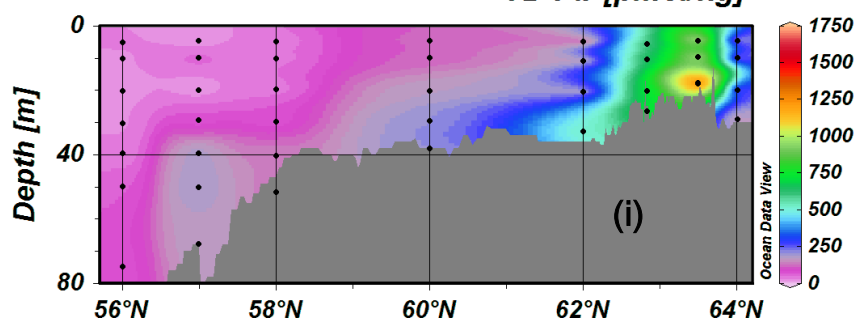

Fig. 6 
LP Al [nmol/kg]

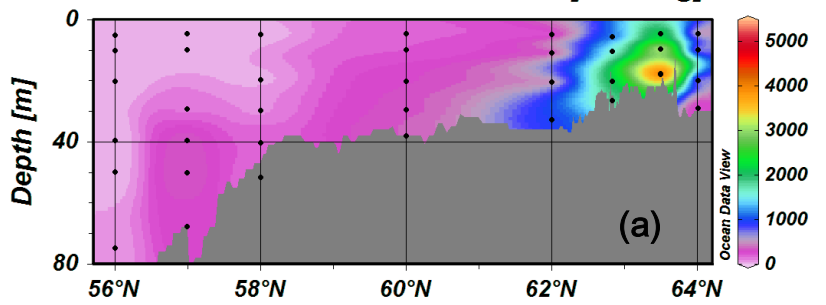

LP Fe [nmol/kg]

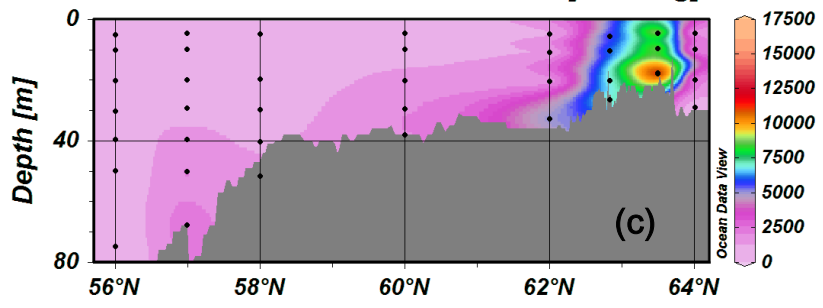

LP Ni [nmol/kg]

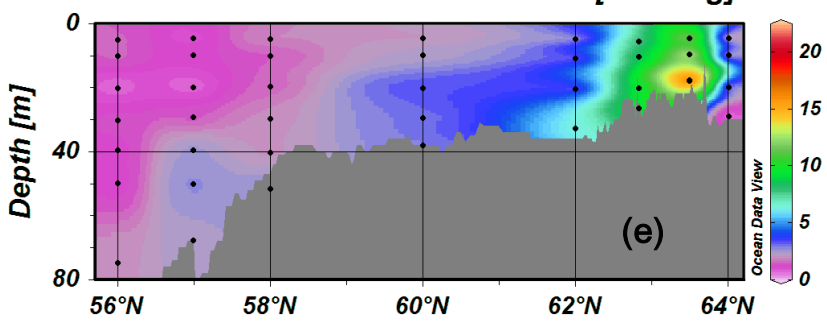

LP Zn [nmol/kg]

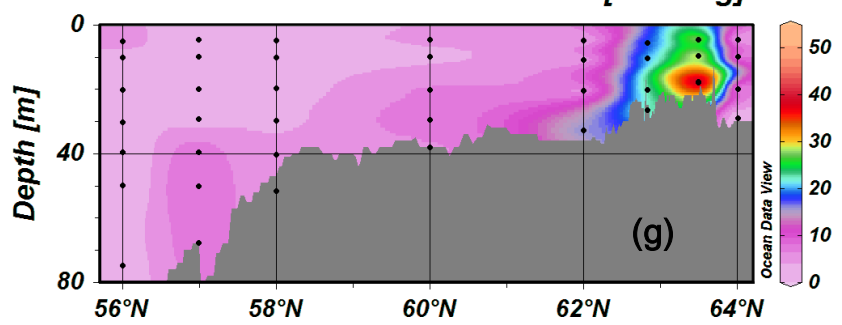

LP Pb [pmol/kg]

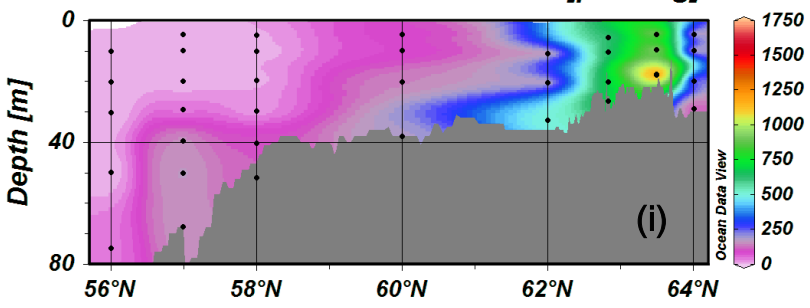

LP Mn [nmol/kg]

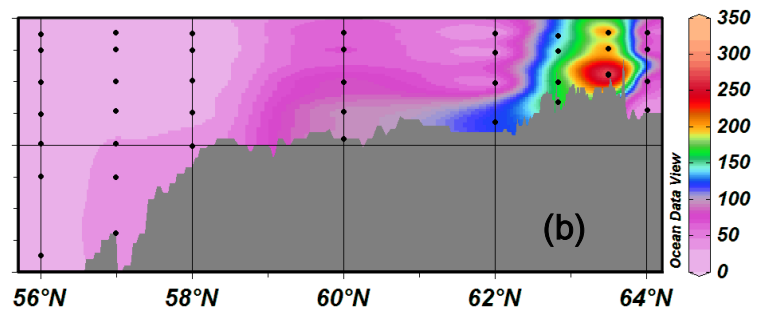

LP Co $[\mathrm{pmol} / \mathrm{kg}]$

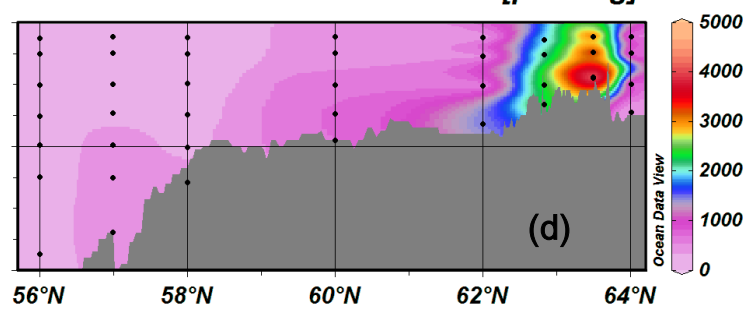

LP Cu [nmol/kg]

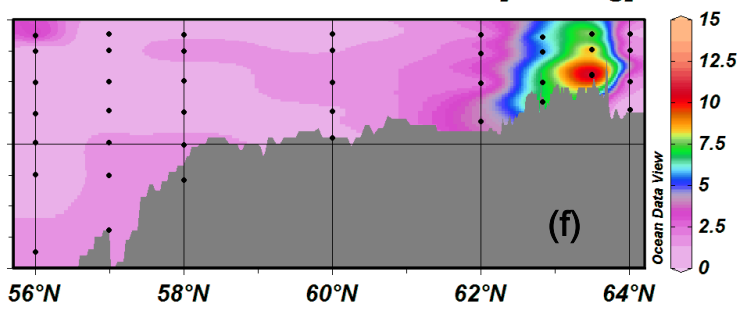

LP Cd [nmol/kg]

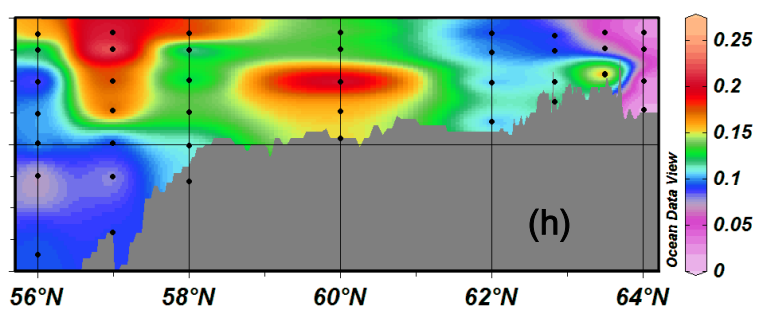

Fig. 7 


$$
\smile \text { Al } \quad-\mathrm{Fe}-\mathrm{-C}-\mathrm{Co} \quad \cdots \cdot \mathrm{Ni} \quad \bullet-\mathrm{Cd}
$$

Station BR0-

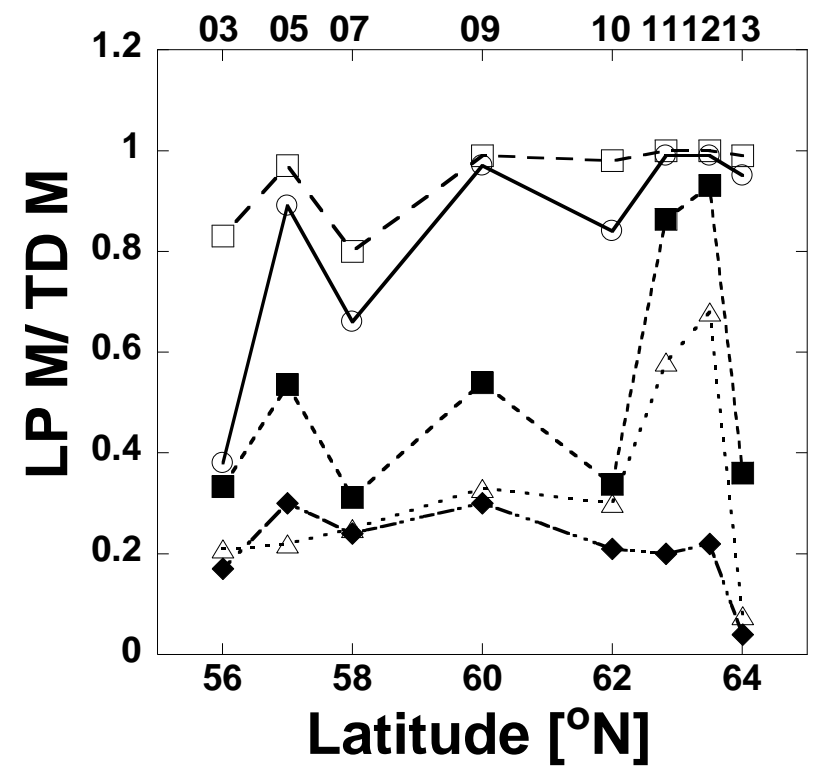

Fig. 8 

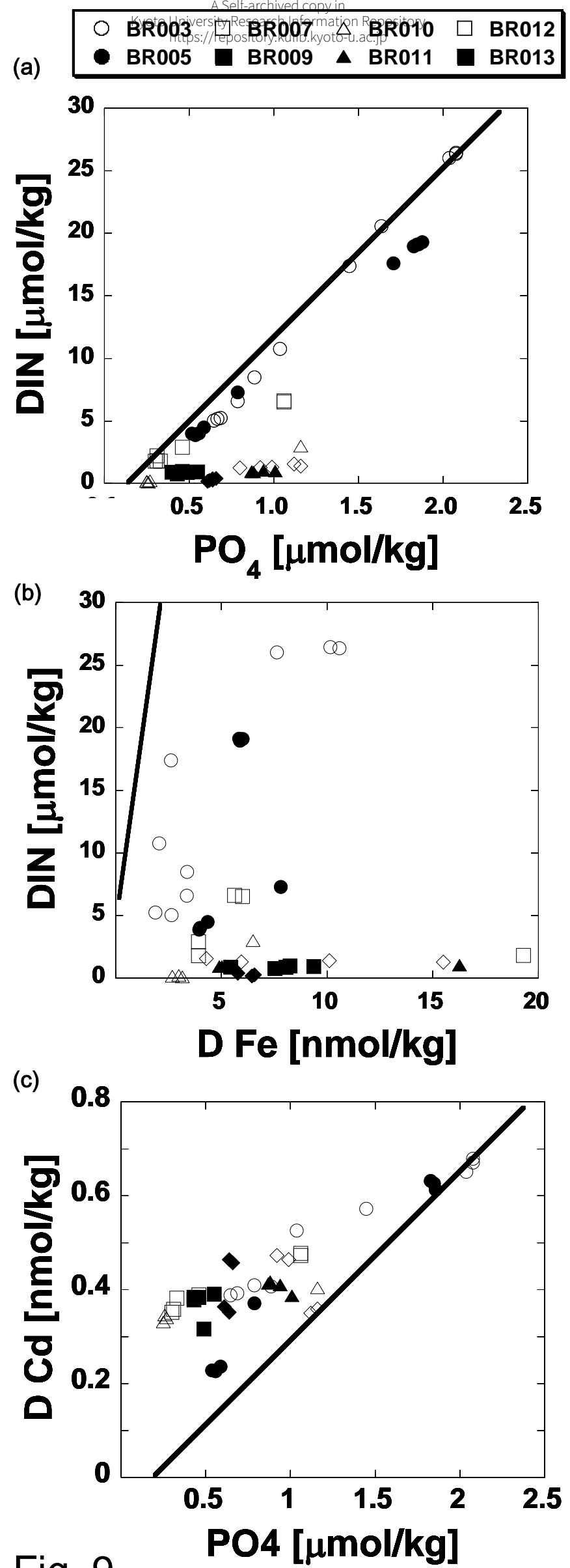

Fig. 9 


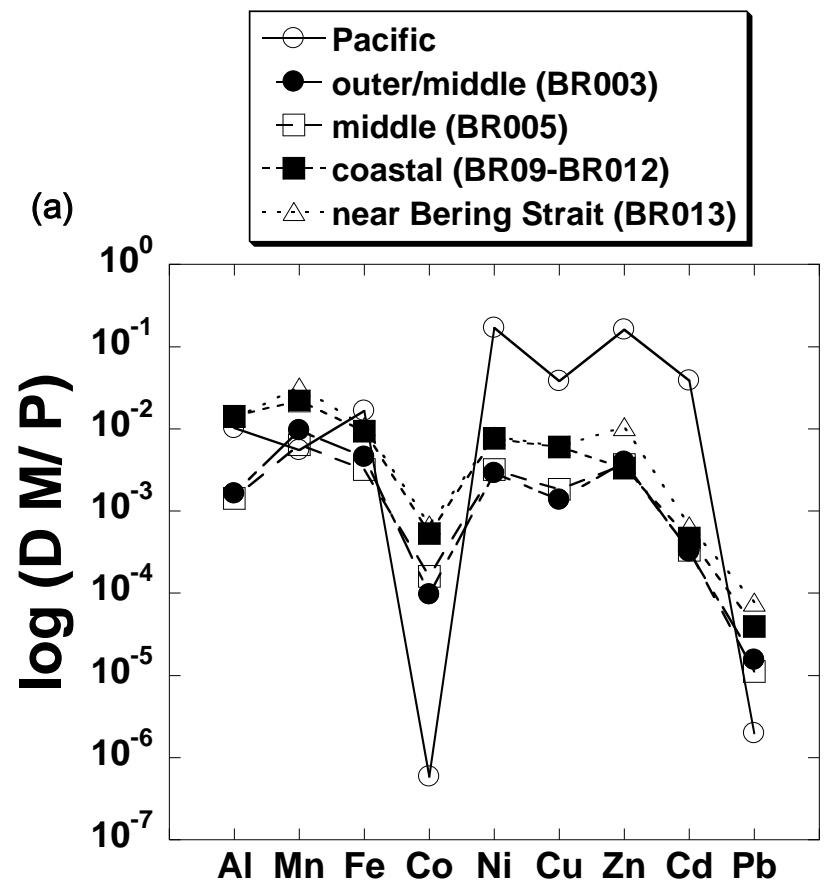

(b)

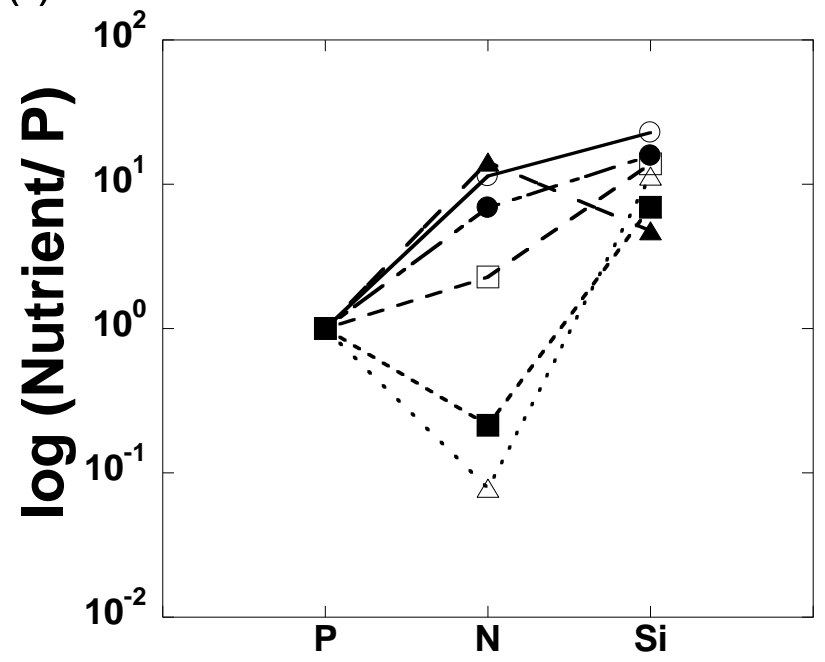

Fig. 10 


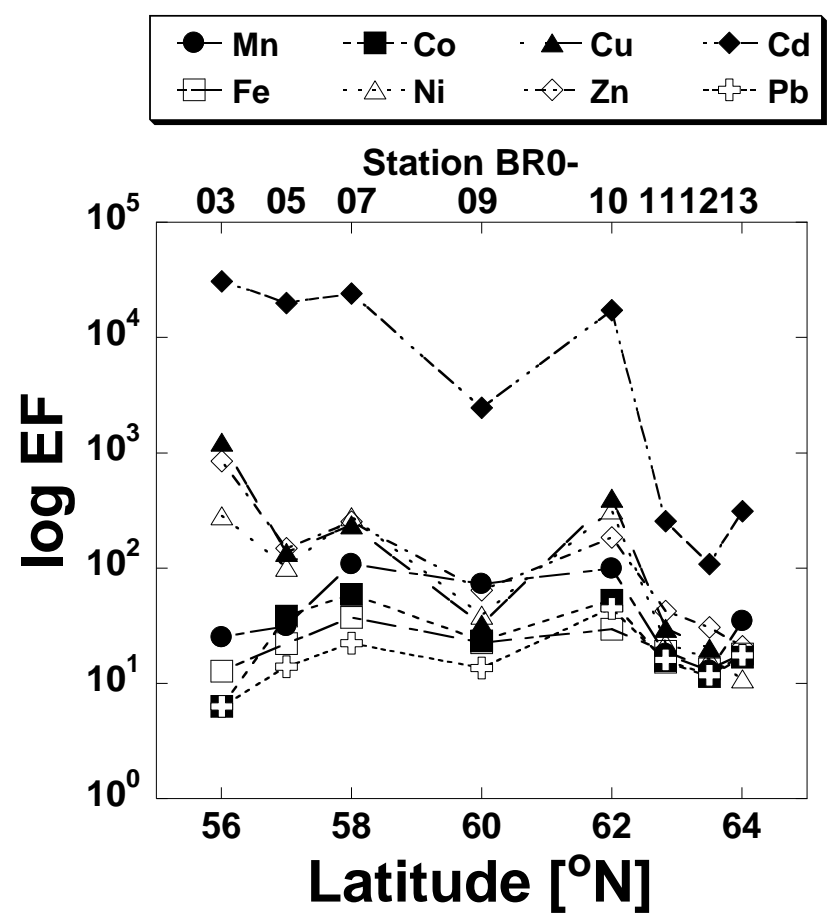

Fig. 11 


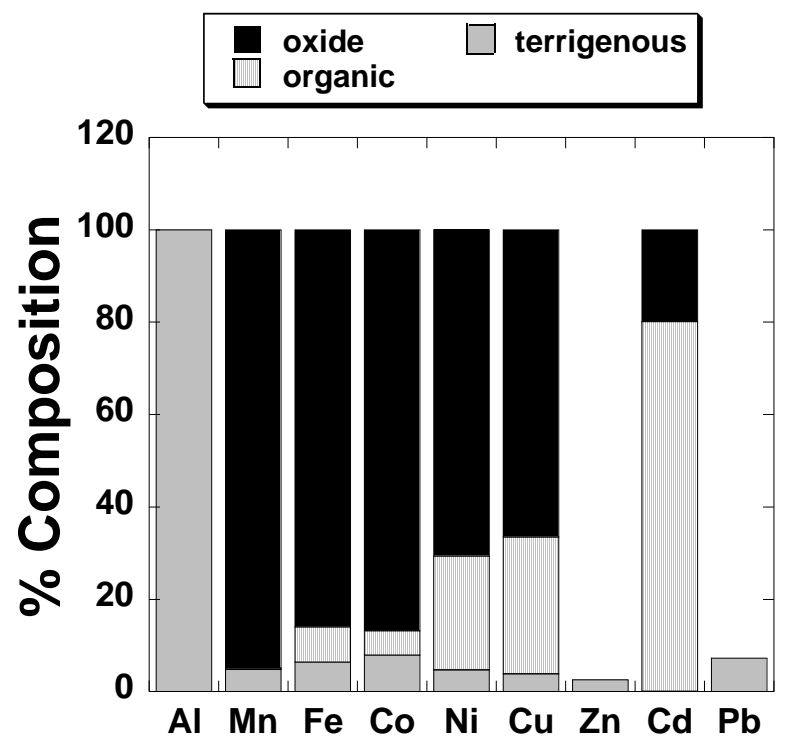

Fig. 12 
Table 1. Procedure blank, detection limit, and NASS-5 analysis

\begin{tabular}{|c|c|c|c|c|c|c|c|c|}
\hline \multirow{3}{*}{$\begin{array}{r}\text { Element } \\
\mathrm{Al}(\mathrm{nmol} / \mathrm{kg})\end{array}$} & \multirow{2}{*}{\multicolumn{2}{|c|}{$\begin{array}{l}\text { Procedure blank }{ }^{\mathrm{a}} \\
\qquad(\mathrm{n}=3)\end{array}$}} & \multirow{3}{*}{$\begin{array}{c}\text { Detection limit }^{\mathrm{b}} \\
0.17\end{array}$} & \multicolumn{5}{|c|}{ NASS $-5^{\text {a }}$} \\
\hline & & & & \multicolumn{2}{|c|}{ Certified } & \multicolumn{3}{|c|}{$\begin{array}{l}\text { Observed } \\
\qquad(\mathrm{n}=3)\end{array}$} \\
\hline & 0.26 & 0.06 & & & & 2.66 & \pm & 0.35 \\
\hline $\mathrm{Mn}(\mathrm{nmol} / \mathrm{kg})$ & $\mathrm{ND}^{\mathrm{c}}$ & & 0.01 & 16.7 & 1.0 & 15.1 & \pm & 1.8 \\
\hline $\mathrm{Fe}(\mathrm{nmol} / \mathrm{kg})$ & 0.04 & 0.01 & 0.04 & 3.62 & \pm 0.61 & 3.69 & \pm & 0.60 \\
\hline Co (pmol/kg) & ND & & 1.2 & 182 & 50 & 173 & \pm & 0.2 \\
\hline $\mathrm{Ni}(\mathrm{nmol} / \mathrm{kg})$ & ND & & 0.01 & 4.21 & \pm 0.47 & 3.85 & \pm & 0.12 \\
\hline $\mathrm{Cu}(\mathrm{nmol} / \mathrm{kg})$ & ND & & 0.01 & 4.56 & \pm 0.71 & 3.32 & \pm & 0.14 \\
\hline $\mathrm{Zn}(\mathrm{nmol} / \mathrm{kg})$ & ND & & 0.09 & 1.52 & \pm 0.58 & 1.13 & \pm & 0.05 \\
\hline $\mathrm{Cd}(\mathrm{nmol} / \mathrm{kg})$ & ND & & 0.009 & 0.20 & \pm 0.03 & 0.21 & \pm & 0.001 \\
\hline $\mathrm{Pb}(\mathrm{pmol} / \mathrm{kg})$ & 0.85 & 0.11 & 0.34 & 37.7 & \pm 23.5 & 33.8 & \pm & 0.4 \\
\hline
\end{tabular}


Table 3. The correlation matrix of acid dissolvable trace metals, temperature and salinity for the pool of all data in the Bering Sea

\begin{tabular}{|c|c|c|c|c|c|c|c|c|c|c|c|}
\hline & $\mathrm{T}$ & $S$ & $\mathrm{TD}-\mathrm{Al}$ & TD-Mn & TD-Fe & TD-Co & TD-Ni & $\mathrm{TD}-\mathrm{Cu}$ & TD-Zn & $\mathrm{TD}-\mathrm{Cd}$ & $\mathrm{TD}-\mathrm{Pb}$ \\
\hline $\mathrm{T}$ & 1.00 & -0.39 & 0.40 & 0.34 & 0.31 & 0.36 & 0.39 & 0.40 & 0.30 & -0.36 & 0.34 \\
\hline$S$ & & 1.00 & -0.67 & -0.69 & -0.70 & -0.75 & -0.72 & -0.77 & -0.54 & 0.49 & -0.72 \\
\hline TD-Al & & & 1.00 & 0.94 & 0.96 & 0.97 & 0.97 & 0.95 & 0.94 & -0.01 & 0.97 \\
\hline TD-Mn & & & & 1.00 & 0.97 & 0.98 & 0.95 & 0.92 & 0.91 & 0.00 & 0.97 \\
\hline TD-Fe & & & & & 1.00 & 0.99 & 0.99 & 0.97 & 0.96 & 0.06 & 1.00 \\
\hline $\mathrm{TD}-\mathrm{Co}$ & & & & & & 1.00 & 0.98 & 0.96 & 0.93 & -0.02 & 0.99 \\
\hline TD-Ni & & & & & & & 1.00 & 0.98 & 0.96 & 0.07 & 0.99 \\
\hline $\mathrm{TD}-\mathrm{Cu}$ & & & & & & & & 1.00 & 0.93 & 0.00 & 0.97 \\
\hline TD-Zn & & & & & & & & & 1.00 & 0.18 & 0.96 \\
\hline $\mathrm{TD}-\mathrm{Cd}$ & & & & & & & & & & 1.00 & 0.01 \\
\hline $\mathrm{TD}-\mathrm{Pb}$ & & & & & & & & & & & 1.00 \\
\hline
\end{tabular}


Table 2. The correlation matrix of dissolved trace metals, temperature, salinity, oxygen and nutrients for the pool of all data in the Bering Sea

\begin{tabular}{|c|c|c|c|c|c|c|c|c|c|c|c|c|c|c|c|c|c|}
\hline & $\mathrm{T}$ & $\mathrm{S}$ & $\mathrm{Si}(\mathrm{OH})_{4}$ & $\mathrm{NO}_{3}$ & $\mathrm{NO}_{2}$ & $\mathrm{NH}_{3}$ & $\mathrm{PO}_{4}$ & Chl. a & $\mathrm{D}-\mathrm{Al}$ & D-Mn & $\mathrm{D}-\mathrm{Fe}$ & $\mathrm{D}-\mathrm{Co}$ & D-Ni & $\mathrm{D}-\mathrm{Cu}$ & $\mathrm{D}-\mathrm{Zn}$ & $\mathrm{D}-\mathrm{Cd}$ & $\mathrm{D}-\mathrm{Pb}$ \\
\hline $\bar{T}$ & 1.00 & -0.39 & -0.52 & -0.46 & -0.37 & -0.76 & -0.54 & 0.34 & 0.45 & -0.11 & -0.03 & -0.14 & 0.33 & 0.38 & -0.15 & -0.50 & 0.21 \\
\hline S & & 1.00 & 0.73 & 0.72 & 0.43 & 0.39 & 0.43 & -0.08 & -0.53 & -0.01 & -0.11 & -0.44 & -0.60 & -0.86 & 0.38 & 0.41 & 0.03 \\
\hline $\mathrm{Si}(\mathrm{OH})_{4}$ & & & 1.00 & 0.99 & 0.61 & 0.66 & 0.86 & -0.40 & -0.32 & 0.03 & 0.08 & -0.54 & -0.08 & -0.42 & 0.55 & 0.80 & -0.07 \\
\hline $\mathrm{NO}_{3}$ & & & & 1.00 & 0.61 & 0.61 & 0.85 & -0.43 & -0.32 & 0.01 & 0.03 & -0.57 & -0.07 & -0.41 & 0.54 & 0.79 & -0.05 \\
\hline $\mathrm{NO}_{2}$ & & & & & 1.00 & 0.75 & 0.74 & -0.40 & -0.14 & -0.33 & -0.16 & -0.56 & 0.21 & -0.14 & 0.55 & 0.60 & -0.01 \\
\hline $\mathrm{NH}_{3}$ & & & & & & 1.00 & 0.78 & -0.40 & -0.22 & -0.17 & 0.03 & -0.23 & 0.01 & -0.21 & 0.44 & 0.72 & -0.15 \\
\hline $\mathrm{PO}_{4}$ & & & & & & & 1.00 & -0.55 & -0.11 & 0.11 & 0.14 & -0.41 & 0.28 & -0.02 & 0.58 & 0.86 & -0.01 \\
\hline Chl. a & & & & & & & & 1.00 & 0.12 & -0.05 & 0.03 & 0.06 & -0.12 & -0.02 & -0.55 & -0.70 & -0.11 \\
\hline $\mathrm{D}-\mathrm{Al}$ & & & & & & & & & 1.00 & 0.04 & 0.75 & 0.07 & 0.60 & 0.69 & -0.03 & -0.17 & 0.36 \\
\hline D-Mn & & & & & & & & & & 1.00 & 0.37 & 0.64 & 0.01 & 0.08 & -0.04 & 0.17 & 0.15 \\
\hline $\mathrm{D}-\mathrm{Fe}$ & & & & & & & & & & & 1.00 & 0.24 & 0.29 & 0.27 & 0.05 & 0.16 & 0.24 \\
\hline $\mathrm{D}-\mathrm{Co}$ & & & & & & & & & & & & 1.00 & -0.06 & 0.15 & -0.40 & -0.19 & 0.02 \\
\hline D-Ni & & & & & & & & & & & & & 1.00 & 0.84 & 0.08 & 0.11 & 0.13 \\
\hline $\mathrm{D}-\mathrm{Cu}$ & & & & & & & & & & & & & & 1.00 & -0.11 & -0.16 & 0.16 \\
\hline $\mathrm{D}-\mathrm{Zn}$ & & & & & & & & & & & & & & & 1.00 & 0.64 & 0.27 \\
\hline $\mathrm{D}-\mathrm{Cd}$ & & & & & & & & & & & & & & & & 1.00 & -0.05 \\
\hline $\mathrm{D}-\mathrm{Pb}$ & & & & & & & & & & & & & & & & & 1.00 \\
\hline
\end{tabular}


Table 4. The correlation matrix of labile particulate trace metals, temperature, salinity and Chl. a for the pool of all data in the Bering Sea

\begin{tabular}{|c|c|c|c|c|c|c|c|c|c|c|c|c|}
\hline & $\mathrm{T}$ & $\mathrm{S}$ & Chl. a & LP-Al & LP-Mn & LP-Fe & LP-Co & LP-Ni & $\mathrm{LP}-\mathrm{Cu}$ & LP-Zn & LP-Cd & LP-Pb \\
\hline $\mathrm{T}$ & 1.00 & -0.39 & 0.34 & 0.48 & 0.36 & 0.31 & 0.44 & 0.39 & 0.37 & 0.33 & 0.26 & 0.51 \\
\hline$S$ & & 1.00 & -0.08 & -0.66 & -0.71 & -0.70 & -0.71 & -0.72 & -0.70 & -0.69 & 0.13 & -0.74 \\
\hline Chl. a & & & 1.00 & -0.07 & -0.01 & -0.07 & -0.06 & -0.06 & -0.10 & -0.09 & 0.68 & -0.05 \\
\hline LP-Al & & & & 1.00 & 0.95 & 0.96 & 0.98 & 0.97 & 0.96 & 0.97 & -0.01 & 0.97 \\
\hline LP-Mn & & & & & 1.00 & 0.98 & 0.98 & 0.97 & 0.94 & 0.97 & 0.02 & 0.98 \\
\hline LP-Fe & & & & & & 1.00 & 0.99 & 0.99 & 0.97 & 0.99 & -0.05 & 1.00 \\
\hline LP-Co & & & & & & & 1.00 & 0.99 & 0.98 & 0.99 & -0.01 & 1.00 \\
\hline LP-Ni & & & & & & & & 1.00 & 0.98 & 0.99 & 0.03 & 0.99 \\
\hline $\mathrm{LP}-\mathrm{Cu}$ & & & & & & & & & 1.00 & 0.98 & -0.08 & 0.99 \\
\hline LP-Zn & & & & & & & & & & 1.00 & -0.04 & 0.99 \\
\hline LP-Cd & & & & & & & & & & & 1.00 & -0.01 \\
\hline LP-Pb & & & & & & & & & & & & 1.00 \\
\hline
\end{tabular}

